The Natal Militia: Defence of the Colony, 1893-1910

\author{
Paul Thompson \\ University of KwaZulu-Natal
}

In no part of the British Empire is the subject of Defence of more importance than in the Colony of Natal, a Colony that I am justified in describing as one of the most dangerous corners of the Empire. In the past it has been the cockpit of South Africa, and it may yet keep up its unpleasant reputation.

- $\quad$ Lieutenant-Colonel H.P. Leader, Commandant of Natal Volunteers, $1902^{1}$

[...]With the large semi-barbarous and warlike Native races of South Africa, wars have been frequent in the past, and war in the future is a contingency that must be provided for. It is the most natural way of asserting himself which the Native has, and if the white man is to remain master here, he must not only govern wisely and humanely, but be always ready to meet force with superior force if necessary.

- $\quad$ Lieutenant-Colonel H.T. Bru-de-Wold, Commandant of Natal Militia, $1907^{2}$

\title{
Introduction
}

The British Colony of Natal became self-governing in 1893. "Responsible government”, as self-government was called at the time, required a polity of British settlers sufficiently mature to organize and maintain a society in normal circumstances. It was part of the evolution of settlement in the British Empire, but there were wide differences between British colonies in America, Africa and the Antipodes, especially in respect of the indigenous populations upon whose living space the Europeans intruded. The population of Natal was estimated at 584,326 in 1894, of which 503208 were Africans, 35,411 were Indians and only 45,707 were Europeans. ${ }^{3}$ It was unusual for so few Europeans to have charge of other groups, and indeed the British Crown reserved the right to approve Colonial legislation

\footnotetext{
${ }^{1}$ Colony of Natal, Report of the Commandant of Volunteers for the Year 1902 [Pietermaritzburg, Davis, 1903], p. 1.

${ }^{2}$ Natal Government Gazette (hereafter cited as NGG) 3625A (Supplement No. 17, Oct. 1, 1907), Government Notice 56 of 1907 (Sept. 24, 1907): Annual Report of the Commandant of Militia for 1906 (hereafter cited as CR 1906), p. 1033. Commandant's Reports will be cited as CR with the appropriate year and as CGR for 1908 and 1909.

${ }^{3}$ Colony of Natal, Statistical Year Book for the Year 1901 (cited hereafter as SYB; Pietermaritzburg, Davis, 1902), p. 3.
} 
governing them or not. ${ }^{4}$

Responsible government entailed self-defence. A colony was expected to establish a defence force of its own on a sound footing. Of course, it was not expected to repel strong foreign enemies single-handedly - Imperial forces would do that and the colonial ones would assist them - but it was expected to deal with internal troubles. There was an Imperial garrison at Fort Napier, in the colonial capital of Pietermaritzburg, but it was understood that this would be withdrawn in five years, during which time the Colony would make its defensive arrangements. ${ }^{5}$

It is the purpose of this article to describe the establishment of Natal's defence force and its career from 1893 to 1910, the period in which the Colony enjoyed responsible government. The article stresses that Natal was a frontier society, and the settler population had the two-fold duty of protecting themselves against a large indigenous population which they perceived increasingly as inimical to their regime, and of cooperating with Imperial authorities in securing South Africa and the Empire. These duties led rapidly to a militarization of settler society and the modernization of military structures and matériel. ${ }^{6}$

\section{The Volunteer Force}

The Colony had a variety of small military corps based in the few towns and scattered country centres. They consisted of men who had volunteered for service. They were armed and uniformed by the government, but their tours of duty and military training were limited, and they were greatly inferior compared to the regular troops of the Imperial garrison. In 1895 there were eight corps - four of Mounted Rifles (940 officers and men), two of infantry

\footnotetext{
${ }^{4}$ See Edgar H. Brookes and Colin deB. Webb, A History of Natal (Pietermaritzburg, University of Natal Press, 1965), pp. 176-180; and Bill Guest, “Towards responsible government,” chapter 9 in Natal and Zululand From Earliest Times to 1910: A new history (edited by Andrew Duminy and Bill Guest; Pietermaritzburg, University of Natal Press and Shuter \& Shooter, 1989), pp. 245-246.

${ }^{5}$ Sir Henry McCallum, quoted in The Natal Mercury, Jan. 28, 1905: “The Colony’s Defences,” cutting in Archives of the Lieutenant-Governor and Governor of the Colony of Natal (1842-1910), hereafter cited as GH (for “Government House”), Volume 510, Minute G179/1905, p. 155. This and other records groups are in the Pietermaritzburg Archives Repository of the Natal Archives. Documents are cited by volume, minute, and page, as applicable.

${ }^{6}$ Contemporary terminology which is used in this article is intended simply to preserve an historical context. This is necessary for an accurate understanding of legal (such as "Native”, "Location”, and "tribe”) and military terms (such as "departmental corps", "special service”, and "magazine rifle”). The author is aware that some contemporary terms may be jarring to readers unaccustomed to them, and seeks to avoid those which may be offensive.
} 
(422), one of field artillery (84 and four guns) and one of coastal artillery, but was called a naval corps (86 and two guns). Altogether they numbered 1,532 officers and men. ${ }^{7}$

The responsible government put these on a firm footing by the Volunteer Act, No. 23 of 1895. The existing corps could be combined or disbanded, and new corps could be formed, at the discretion of the Governor, the Crown's representative in the Colony, who was commander-in-chief of the Volunteer Force; however, he was to appoint a Commandant (who would actually command it) and the officers of the Permanent Staff, with headquarters in the capital. The Commandant could nominate staff and field officers for the Governor's approval. The officer commanding a corps could appoint officers in it, but only if they were first elected by at least half of the members of the corps. Service in the corps was for three years. A Volunteer had to take the oath of allegiance to the Queen, and could not be a member of any other corps. The Governor could order out all or part of the Volunteer Force "for military service in aid of the civil power, or against an enemy or to repel invasion", in which event they might be placed under the Imperial officer commanding Her Majesty's Forces in the Colony. ${ }^{8}$

Colonel John G. Dartnell, an officer of energy and experience, was continued in office. He had been commissioned in the $86^{\text {th }}$ Regiment in 1855 , distinguished himself and received promotion during the Indian Mutiny, and retired as a Major. In 1872 he had come to Natal, where he organized the Colony’s Mounted Police in 1874, and also was appointed Commandant of Volunteers. ${ }^{9}$

The bulk of the Volunteer Act dealt with administration and discipline, which were embodied in a set of regulations. The Act came into force at the beginning of $1896,{ }^{10}$ and

\footnotetext{
${ }^{7}$ Colony of Natal, Departmental Reports 1895, Report of the Commandant of Volunteers for the Year 1894-95: F51 (Annexure B). The total had been 1490 at the end of 1893 (ibid. 1893-4: F1). The Commandant's Reports for 1895-1900 appear in the annual compilations Departmental Reports and thereafter as separate publications. ${ }^{8}$ Colony of Natal, Acts of the Parliament of the Colony of Natal, passed in the Session of the Year 1895, being the Third Session of the First Colonial Parliament (Pietermaritzburg, William Watson, 1895), pp. 49-59: Act No. 23 of 1895. The Act is also reproduced in Eric Goetzsche, "Rough but Ready": An Official History of the Natal Mounted Rifles and Its Antecedent and Associated Units 1854-1969 [Durban, Natal Mounted Rifles, 197], pp. 96-101.

${ }^{9}$ See and cf H.P. Holt, The Mounted Police of Natal (London, John Murray, 1913), pp. 13-15; J. Stuart, A History of the Zulu Rebellion 1906 and of Dinuzulu's Arrest, Trial and Expatriation (London, Macmillan, 1913), pp. 38-39. Darrell Hall, The Hall Handbook of the Anglo-Boer War 1899-1902 (edited by Fransjohan Pretorius and Gilbert Torlage; Pietermaritzburg, University of Natal Press, 1999), p. 94

${ }^{10}$ CR 1896: F45.
} 
during the next few years Dartnell organized the Volunteer Force on modern lines. The individual corps uniforms were replaced by the standard khaki of Imperial units. ${ }^{11}$ District Adjutants were appointed for the mounted troops. They made house-to-house inspections in the towns but also increased contact in the country districts. They gave special attention to drill, care of equipment and care of horses, and checked irregularities that corps officers failed to notice. An 'undesirable element' existed especially in the mounted corps, and these 'wasters' were weeded out and turned away. By 1899, the failure to maintain horses properly was largely confined to the towns, notably Durban, where men knew little about horses because very few owned them. ${ }^{12}$

Recruits were assisted to buy uniforms and equipment from Corps Funds, but these proved inadequate, and in 1897 the government increased the capitation grant to corps from $£ 2$ to $£ 3$ which enabled them to provide these items without further cost from their funds. In 1897 the government made a special grant of $£ 2,500$ and in 1898 increased the Remount Fund so that mounted corps could make loans to young men who needed to buy horses in order to join. $^{13}$

Men in the mounted corps provided their own horses, which the government insured for service, and there had been many abuses, especially in the towns, where men would borrow or rent them, and these were now checked. Volunteer Headquarters took charge of the Insurance Fund in 1896. This was important in 1897 when there was a severe wave of horse sickness in the coastal districts. Twenty-six percent of the horses of the Durban-based Natal Mounted Rifles died. Practically all the Port Shepstone troop of the Border Mounted Rifles had to be remounted. ${ }^{14}$

Marksmanship was vital, and regular practice was encouraged to improve shooting. There was an annual Volunteer Central Meeting in May, where teams of Volunteers competed for Government Challenge cups. Most represented mounted and infantry units, but even the naval corps sent a team. The infantry and naval corps were rearmed with MartiniMetford carbines and rifles in 1894 - the first colonial units to get them - but they were

\footnotetext{
${ }^{11}$ Ibid. 1895: F46-48; 1897: F1.

12 Ibid. 1896: F45-46; 1897: F42; 1898: F1.

${ }^{13}$ Ibid. 1896: F45; 1897: F1; 1898: F1.

${ }^{14}$ Ibid. 1896: F45; 1897: F2.
} 
heavy for the infantry, and in 1898 Martini-Enfields were issued to them. The mounted men were armed with Swinburne-Henry carbines, many going back to 1876, and Martini-Henrys, which were more recent but whose barrels corroded badly because of the new smokeless powder. The Swinburne-Henrys were replaced by Martini-Metfords, and the Martini-Henrys had their barrels replaced. ${ }^{15}$ Perhaps because of these changes, musketry remained indifferent, but Dartnell put the responsibility on corps officers. The field artillery's cumbersome 9-pounder guns were replaced in 1897, and the corps became a full six-gun battery in 1898. An officer was appointed District Adjutant for artillery and it was arranged that he receive training at Woolwich. ${ }^{16}$

The corps were in the habit of having annual ten-day encampments at convenient times (but most preferred Easter time) and places in their districts. Performance depended largely on the local community, e.g. the Midlands corps generally drilled well and looked smart, but those in the South, while they drilled well, were "somewhat slovenly". Dartnell was particularly concerned at the attitude of employers and employees in Durban who did not like taking so much time off work for infantry and naval training. The camps went well enough in 1895, but Dartnell wanted corps commanders to learn to handle larger units, and in 1896 he organized the mounted units in the Midlands into "flying columns" and ordered the leaders to manoeuvre them together in accord with a "special idea”, and the Durban corps fell in with them. In 1897 the corps were diverted by duty as Rinderpest Guards, and not all could attend camps, which were held separately again. In 1898 he held a general encampment near Richmond for all the corps, at which "field firing under service conditions was carried out to a large extent”. The officer commanding Imperial forces in Natal was invited to attend, and reciprocated by inviting Volunteers to attend the Imperial manoeuvres near Ladysmith. In 1899 the general encampment at Balgowan was visited by the Governor. There were field days with the Imperial troops at Nottingham Road. "Besides the usual Regimental, Squadron, Battery, Troop, and Company drills, the 'attack formation' was practised and carried out satisfactorily.”17

\footnotetext{
${ }^{15}$ Ibid. 1896: F46, F48; 1897: F2; 1898: F2-3.

${ }^{16}$ Ibid. 1896: F46; 1897: F2; 1898: F1-3.

${ }^{17}$ Ibid. 1893-4: F1-4; 1895: F45-47; 1896: F46; 1897: F1-2; 1898: F2; 1899: F1. The Act (Section 3) defined Corps as "a Naval Corps, a Troop of Mounted Rifles, Battery of Artillery, a Company of Infantry, Medical Staff, or Ambulance Volunteers; also any Corps, Troops, companies, when formed into Contingents, Regiments, or Battalions"; a Contingent as "two or more Troops or Companies combined for administrative purposes"; and
} 
Dartnell was pleased with the results. He recalled in 1898 that "many persons foretold the ruin of the [Volunteer] Force”, but the reverse had happened, and he considered the Natal Volunteers "very far ahead in Equipment, Armament, Organization and general fitness to take the field”. ${ }^{18}$ In 1899 they were ready for the South African War.

The strength of the Volunteer Force at the end of 1896 was 1,454 officers and men and at the end of $1898,1,551$ officers and men ${ }^{19}$ - hardly enough to repel an invasion or confront an enemy in large numbers. Obviously in 1898, the Colonial government was thinking of fighting in collaboration with Imperial forces against the Boer Republics. In his annual reports the Commandant mentions no particular enemy, but the thrust of his programme was to provide a defence force for European-style warfare, which suggests fighting the Boer, not the Zulu. But before describing the Volunteers in the war, it is necessary to describe more fully Natal's defence system, for there were other units which were part of it, and the Volunteer Force cannot be considered apart from them.

The Volunteer Act provided for a Reserve Force, but none was organized. Instead the Volunteer Force depended for augmentation and back-up on the Colony's School Cadet Corps and Rifle Associations. Regulations for the organizing of boys in government and government-aided schools into Cadet Corps were approved in 1895, and a capitation grant was made to allow the purchase of uniforms and ammunition and other needs. A standard uniform was adopted; each school had its badge. The boys were issued the old Snider carbines and fifty rounds of ammunition a year. ${ }^{20}$

The Commandant did not envisage attaching the Cadets to the Volunteer Corps, but

\footnotetext{
a Regiment or Battalion as "a combination of any of the above in a body not exceeding an establishment fixed by regulations under the Act for the regiment or battalion". It is not surprising that the terms are used fairly freely in reports and correspondence, and in time an increasing switch from "corps" to "regiment" as units became larger. In this paper I try to be consistent with the use of "corps", but admit to not being quite satisfied with it.

${ }^{18}$ CR 1897: F3. "I know the rooted objections of the average Englishmen to anything approaching military service, as it is styled 'being a soldier'," (1896: F47.) He complained about the "great ignorance" about Volunteer service in the Colony, which he attributed to officers not providing more information about it (and thus attracting new men) at troop meetings (1897: F3).

${ }^{19}$ Ibid. 1896: F49 (Annexure A); 1898: F13.

${ }^{20}$ Ibid. 1895: F49.
} 
regarded them as “a most valuable 'nursery’ for the Volunteer Force”, 21,22

I consider the Cadet movement worthy of every encouragement, as I believe it will prove a valuable factor in fostering a military spirit in the rising generation, as well as providing a feeder to our Volunteer Force. The lads are at an age when the principles of discipline and drill once taught are never forgotten, and I feel sure the Colony and Empire will, in the near future, receive full value from what is now being done.

Aided and abetted by the Natal Education Department the Cadet movement burgeoned. At the first general encampment in July 1896 in Pietermaritzburg, 1,116 Cadets representing twenty-two corps gathered for four days under the supervision of Volunteer Staff, assisted by instructors from the schools. There was a rifle competition held for a challenge shield provided by public subscription (Hilton College won), and on the last day there was an inspection and a march past before the Governor. Next year's encampment was at Lord's Grounds in Durban over five days, with 940 Cadets representing twenty-four corps. There were a signals detachment, an ambulance detachment, a bugle band, and seven drum and fife bands. The boys had Martini-Metford carbines now. Twenty-three schools competed for the Challenge Shield (Hilton won again). Besides the inspection by the commanding officer of the Imperial forces and marched past, there was a "miscellaneous concert” by the boys which approximately 3,000 people attended, and a church service.

In 1898 the camp was at the Agricultural Society's Show Grounds in Pietermaritzburg, attended by 920 Cadets representing twenty-six corps. Nineteen schools competed for the Shield (Maritzburg College won), and there was "White" Cup for the Junior Cadets (Estcourt School won it). The march past took place at the Garrison Polo Ground. The Administrator of the Colony ${ }^{23}$ made a speech and presented the shield and medals. The miscellaneous concert was held in the Town Hall, and the Natal Carbineers band played another evening at the Show Grounds. The Cadets also went to Fillis' Circus, and the $7^{\text {th }}$ Hussars gave a grand Wild West Show for them. At the end of 1898 there were 2,081 Cadets (1,304 under fourteen, 777 over fourteen) in twenty-seven corps, with twenty-six instructors. The 1899 encampment, again at Lord's in Durban, had 995 Cadets of thirty-one corps. (Hilton College won the Shield and Dundee School the Cup.) The mayor took the review and

\footnotetext{
${ }^{21}$ Ibid. 1898: F4.

22 Ibid. 1896: F48.

${ }^{23}$ In the absence of the Governor from the Colony an Administrator was appointed in his stead.
} 
made the presentations at the race track (presumably the military was occupied elsewhere). ${ }^{24}$

The Volunteer Force had to wait a while to reap the full benefits of the Cadet movement, but it had a ready back-up in the Rifle Associations. These had been established in 1862 to organize shooting for the purpose of defence. ${ }^{25}$ There were sixty-two associations in $1898 .^{26}$ Members of the associations could buy rifles and ammunition at cost from the government; however, the government had little control over the associations, and one could decide for itself whether or not to defend its locality in an emergency. ${ }^{27}$

Dartnell had little use for the Rifle Associations until new regulations for them were adopted in 1898. These required members of an association to live in the magisterial division in which it was registered and forbade multiple memberships. A capitation grant of $£ 1$ was made to an association for every member who owned a good rifle and made himself efficient in shooting. In the event of war or disturbance the local magistrate could call them out for service. $^{28}$ Dartnell encouraged marksmanship by competitions, most notably the Annual Central Bisley sponsored by the Natal Rifle Association in Pietermaritzburg. ${ }^{29}$

The existing associations did not have to accept the new regulations, but most of the important ones did. Dartnell wanted those which did not disbanded. He especially wanted all members to take the oath of allegiance to the Queen, ${ }^{30}$ and he was concerned that Boers in the northern districts refused to do so - many said that they would go with the South African Republic in the event of war. Those in the Biggarsberg seemed to be buying an unusually large amount of ammunition. (A police search also discovered some Mauser rifles, but all of them had been registered). ${ }^{31}$ Nonetheless, Dartnell believed that the Rifle Associations now "formed a most valuable home defence force", which could be called out to protect life and

\footnotetext{
${ }^{24}$ CR 1895: F49; 1896: F47-48; 1897: F3-4; 1898: F4; 1899: F2.

${ }^{25}$ [Colony of Natal.] Natal. Laws. 1862 [n.d., n.p.], No. 19, 1862.

${ }^{26}$ Natal Almanac, Directory, and Yearly Register 1898 (Pietermaritzburg, Davis, 1989), p. 589.

27 CR 1896: F47; 1987: F3; 1898: F3. Also, the Natal Rifle Association, the parent body, distributed a government grant of $£ 200$ each year to promote shooting generally; however, it tended to reward top marksmen (ibid. 1894: F5), and Dartnell insisted that it open up competitions to encourage the others to do better (ibid. 1895: F48).

${ }^{28}$ Ibid. 1898: F3.

${ }^{29}$ Ibid. 1895: F48; 1896: F46: 1899: F1, 47.

${ }^{30}$ Ibid. 1899: F2.

31 Departmental Reports 1899, Annual Report of the Chief Commissioner of Police for the Year ending December 1899: F9. The Chief Commissioner's Reports are cited CCP in the same manner as the Commandant's (see n. 6).
} 
property and to prevent panic in an emergency when the local Volunteer Force Corps were called away. ${ }^{32}$

There was also another body, which complemented the Volunteer Force - the Natal Police, of which Dartnell was Chief Commissioner. The various police forces in the Colony had been amalgamated and their functions rationalized by the Police Act of 1894, and the Colony had been divided into eleven policing districts. The Mounted Police, which had been the closest thing Natal had to a standing army, was retained in the guise of an efficient Reserve or Field Force of about 150 men. It was based at headquarters in Pietermaritzburg, and could be despatched to a trouble spot immediately. ${ }^{33}$

Thus on the verge of war in 1899 Natal had, in the event of an emergency, a police field force which could react at once, a Volunteer Force which could be mobilized quickly and deployed, and Rifle Associations which could keep a degree of order in their absence. There was a strong police force stationed in Zululand, ${ }^{34}$ which had been annexed to Natal in 1897. The enemy at this time was perceived to be the South African Republic. The danger was outside the Colony, although there was a potential fifth column of local Boers within.

The South African War and its lessons

The Volunteer Force was called into service when Natal was invaded by Boer forces. All of the corps, except the Umvoti Mounted Rifles which was on duty at Greytown, were involved in the fighting around Ladysmith between October 1899 and June 1900. Twentyfive Rifle Associations were called out. The campaign in Natal having ended, the Volunteers were disbanded in October 1900, but a Volunteer Composite Regiment of 300 men was formed for further service. The Volunteer forces were remobilized for a month and joined “Mills’ Mobile Column”, and the Rifle Associations were again put on alert to meet another Boer invasion through Zululand in the spring of 1901. There were no Cadet encampments

\footnotetext{
${ }^{32}$ CR 1898: F3.

${ }^{33}$ CCP 1895: F1-2; 1896: F1; 1897. The Mounted Police had been established in 1878 (Act No. 6) as a semimilitary unit - although it never got the artillery troop for which the law provided - and then frequently criticized by those who did not like this military aspect. It was later overextended by various government duties, ranging from the suppression of local disorders to the manning of quarantine stations against smallpox. (Ibid. 1803-4: F23-24.)

${ }^{34}$ Ibid. 1898: F18-19, 23.
} 
and no Bisleys in 1900 and $1901 .^{35}$

The Natal Police was also involved in operations around Greytown and Ladysmith, where the northern districts' units were besieged along with the Imperial and other Colonial troops. The Native Police in Zululand was augmented and had several skirmishes with small Boer forces. The Field Force remained in reserve, and otherwise the police had their hands full with security, handling refugees, and then ferreting out enemy collaborators. ${ }^{36}$

The Volunteers lost 181 officers and men in 1899-1900, most of them in the operations around Ladysmith. ${ }^{37}$ In disbanding them, Field Marshal Lord Roberts telegraphed the Governor: "Please convey to the Prime Minister and Government of Natal my high appreciation of the conduct of the Volunteers, and the spirit of the Colony in maintaining them so long”. ${ }^{38}$ This was less than effusive praise, and, on reflection, Natal's contribution to British victory does seem rather modest. Major A.T.G. Wales of the Staff wrote the Commandant's report for 1901. Almost parenthetically, he added to it: "When the country is again on a peace footing, it will be necessary to make a general re-organisation of the Volunteer forces of Natal, past experience proving of great value in the preparations for the future". 39

Dartnell had resigned as Commandant of Volunteers, but remained Chief Commissioner of Police. Lieutenant-Colonel William Royston, commander of the Natal Carbineers from 1881 to 1889, and Staff Officer of Volunteers since 1889, succeeded him as Commandant in $1898 .^{40}$ Both Dartnell and Royston had been besieged in Ladysmith. Royston died soon afterwards, and Dartnell resumed the commandantship. This it was largely nominal, since he was away in the field, first as leader of the Volunteer Composite Regiment in northern Natal, then of different Imperial units in the Transvaal and the Orange Free State, and, finally, again in Natal. When the war ended in 1902, Dartnell was sixty-four. He resigned, took leave, and retired to England in 1903. Major George Mansel, long-time

\footnotetext{
${ }^{35}$ CR 1899: F3; 1900: F1-8; 1901, pp. 3, 15-17. 1902, p. 3.

${ }^{36}$ CCP 1899: F9-11; 1900: F12-13, 17; 1901, pp 4-6.

${ }^{37}$ CR 1900: F3-7.

${ }^{38}$ Ibid. F2.

${ }^{39}$ Ibid. 1901, p. 4.

${ }^{40}$ Colony of Natal, The Natal Civil Service List, corrected to $13^{\text {th }}$ June 1899 (Pietermaritzburg, Davis, 1899), p. 189.
} 
commander of the Zululand police, succeeded him as Chief Commissioner of Police. ${ }^{41}$

Dartnell's successor as Commandant was an Imperial officer, Lieutenant-Colonel Henry Peregrine Leader, $6^{\text {th }}$ Dragoon Guards. The government took some time and care with the appointment, which took effect on July 1, 1902. ${ }^{42}$ The Imperial authorities wanted a recreation of the Colony's defence force; Leader would oversee it and "institute such other radical changes as might appear imperative”. ${ }^{43}$

In his first annual report, Colonel Leader expressed his surprise on discovering that Natal was “entirely dependent on the Mother Country” for its defence. If Imperial troops left the Colony, it would be "practically undefended". He estimated that Natal had 12,000 men available to defend it, but only 2,000 Volunteers were liable to do so. "Nine thousand ablebodied men were content to have their Colony invaded." If they had been embodied and put on the border before the ultimatum, the result, he implied, might have been different. ${ }^{44}$ It was time for a change:

The organisation of the Volunteer Force was perhaps the best suited for the past, when Imperial obligations were less pressing than they are at present; when, too, Imperial Troops [were] counted upon for any emergency that might arise. The test for War, however, has [proved] this organisation a failure, a failure as far as self-defence is concerned. ${ }^{45}$

The feeling among Volunteers cannot be gauged, but Wales' remark above suggests an awareness of the need for change. Lieutenant-Colonel Hilmer Theodore Bru-de-Wold, District Adjutant in the South, who had led the Volunteer Force at the border in the spring of 1901, delivered a bitter post mortem on the Volunteer system a few years later, after he became Commandant:

\footnotetext{
${ }^{41}$ Holt, Mounted Police of Natal, pp. 149, 167-168, 174, 181. Stuart, Zulu Rebellion, p. 39. CCP 1901, pp.3-4; 1903, p. 3

${ }^{42}$ CR 1902, p. 1. GH 511: G313/02, Governor to Prime Minister and reply, Mar. 21, 1902. There were several applicants for the position, but Col. E.M. Greene, of the Natal Carbineers, persuaded the Prime Minister and retiring Commandant that another Imperial officer, Lieut.-Col. W.R. Birdwood, should be appointed; however, Birdwood declined, but he recommended Leader, then commanding the $1^{\text {st }}$ Battalion, Scottish Horse, "in De la Rey country": "a $1^{\text {st }}$ rate officer in the field, popular with officers and men", who "will suit you in every way" The Prime Minister wrote to Lord Kitchener, requesting his secondment for five years. At the time Leader was thirty-seven years old and had been in service seventeen years. (See correspondence in GH 497, pp. 41-44: G196/20; and 543, pp. 52-89: G1378/01.) Leader was also appointed Controller of Arms from July 1, 1904. (Colony of Natal, The Natal Civil List, 1904 (Pietermaritzburg, Davis, 1904), p. 213.)

${ }^{43}$ Stuart, Zulu Rebellion, p. 41.

${ }^{44}$ CR 1902, p. 2.

${ }^{45}$ Ibid.
} 
The Boer War killed Volunteering in Natal. Undoubtedly our Volunteers turned out with alacrity in 1899, eager to defend their country against the invader; but, having spent over a year in the Field, patiently and cheerfully, performing duties of the most arduous, and sometimes the most distasteful, nature, many of them returned to their homes to find business ruined, occupations gone, and future prospects nil; whilst their neighbours, who had remained behind, even when the Colony was in the clutches of the enemy, and practically at its last gasp, were prosperous, with extended business and bulging purses, having lived in health and comfort, while the Volunteers defended them and their interests. The Volunteer pondered over this, and learned his lesson, with the result that, after the War, our Regiments dwindled to half size. ${ }^{46}$

In 1893, the Colony of Natal had been given five years in which to put its defences in order before the Imperial garrison was withdrawn. At the end of that time an Imperial crisis upset all plans and the South African War showed that not nearly enough had been done. The Colony’s time was up, but it seemed it would have to start all over again.

In 1902 the Utrecht-Vryheid district of the Transvaal was annexed to Natal. The Natal Border Police, a temporary unit, was established to keep the peace in the new territory, ${ }^{47}$ and a Burgher Bill was introduced in parliament to comprehend the greater defence of the Colony, enlarged since 1895 by the addition of the "Northern District" and Zululand. The bill was crude, and was withdrawn. An ad-hoc defence commission was set up which took evidence and reported "upon the general measures proper to be taken for the defence of the Colony, and also to advise as to the most suitable mode of constituting a defence force”. The commission consisted of two members of parliament, two Imperial officers, and three Colonial ones - Bru-de-Wold, Mansel, and Colonel Duncan McKenzie of the Natal Carbineers. ${ }^{48}$ Of course, there was much input from Colonel Leader. ${ }^{49}$ The upshot was a bill "to create a Militia Force" in the 1903 session. The bill was discussed and debated thoroughly and passed by a large majority. It was gazetted in July, but it only came into force the following March, and regulations were issued in December. ${ }^{50}$

\footnotetext{
${ }^{46}$ CR 1906, p. 1038. Leader also found it "incredible” that several large and wealthy business firms refused to let their employees be members of the Active Militia. (Ibid. 1904, p. 9.)

${ }^{47}$ CCP 1902, pp.3; 1903, p. 3; 1904, p. 2.

${ }^{48}$ Colony of Natal, Debates of the Legislative Assembly of the Colony of Natal. First Session of the Fourth Parliament (Pietermaritzburg, Times, 1903), XXXIII, 100. Hereafter this source is cited as Debates, with volume and page numbers. Stuart, Zulu Rebellion, p. 41. NGG 3304 (Feb. 17, 1903): GN 235/1903, Report of the Colonial Defence Commission, Oct. 31, 1902, pp. 168-175. GH 536, pp. 39-40: G670/02, Gov. to PM, June 14, 1902, and reply, June 25, 1902.

${ }^{49}$ CR 1902, pp. 2-3.

${ }^{50}$ NGG 3315 (May 14, 1903), pp. 473-478: GN 272/1903; 3337 (July 7, 1903), pp. 1063-1069: “Legislative Assembly, Natal. Bill No. 2, 1903 (as read a third time, and passed) 'To Create a Militia Force'.” Debates, pp. 100-559 passim; 3440 (Nov. 20, 1904): GN 872/1904 (Dec. 10, 1904), pp. 1693-1729.
} 


\section{The Militia}

The Militia Act, No. 36 of 1903 marked a radical change in attitude and policy. It embraced the idea of compulsory military service, which is the basis of a true Militia. It preserved the administrative structure of the Volunteer Force, but necessarily added much to it.

Every male of European descent between the ages of eighteen and fifty was liable for military service "for the repression of civil disturbance, rebellion or invasion". The Volunteer Force was now called the Active Militia. It comprised men who volunteered (or were balloted to fill up the ranks) and were accepted in the various corps. The peacetime establishment of the Active Militia could not exceed 4,000 officers and men, but the Governor-in-Council could increase the strength in wartime. When called into active service, the Governor-in-Council might place it “under the orders of the Commander of His Majesty's Regular Forces in the Colony, provided such officer shall not be below he substantive rank of Major-General in the Army”.

The old Act's Reserve, which had never been formed, now appeared as the Militia Reserves. There were three classes - First Reserves, comprising unmarried men between eighteen and thirty who were not in the Active Militia; Second Reserves, married men between eighteen and thirty and all men between thirty-one and forty; and Third Reserves, men between forty-one and fifty. The Reserves were to be organized in their districts and to elect their officers, although they would be subject to District Commandants (as the District Adjutants were now called) or other designated leaders if they were embodied and took the field. The Governor could call out the Militia, Active and Reserves, for service when and where they might be needed; only the Third Reserves were guaranteed service in their own districts.

The clauses of the bill pertaining to Militia Reserves had elicited sharp debate in the Legislative assembly over whether or not they should be called up at regular intervals for training and instruction in shooting. Without training they would practically useless, but the government would not have it, ostensibly because voters were not expecting it and would 
react against it. Such was the opposition in the Assembly that the bill might be lost. ${ }^{51}$

Cadets and Rifle Associations continued, but the importance of the latter to home defence would diminish when members were enrolled in the Reserves. The Act also allowed the Governor to call out and organize Africans and Indians. ${ }^{52}$ Indeed, nothing much in fact changed with the passage of the Act. Change depended on what was done in terms of it, and the new Commandant had much to do with that. He started immediately, and did a lot even before the Act came into force.

Leader was an Imperial regular officer, and seems to have been in tune with the reformist impulse in the army following the South African War. He began his first annual report to the Minister with a lecture of several paragraphs on "Imperial Defence" as a collaborative venture of Mother Country and daughter Colonies, leading in due course to the latter's providing Imperial Reserves for the Empire. He stressed the importance of Durban as the lifeline of Empire in the event the Suez Canal closed, and in November 1901, he produced a plan for defence of the port which the Defence Commission approved. ${ }^{53}$

The Active Militia blossomed under his intense cultivation. At the end of 1902 its strength was 1,864 officers and men. It was 3,197 at the end of 1903, and 3,449 at the end of 1904. ${ }^{54}$ There was one general encampment for the Mounted Rifles, Field Artillery, and the composite Natal Royal Regiment, and another for the Durban Light Infantry in 1903. They went well, but there were so many recruits by 1904 that the annual general encampment had to be abandoned in favour of more manageable regimental ones. ${ }^{55}$ Corps borrowed from banks to buy uniforms, and Leader got the government to make grants for them. ${ }^{56}$ They were

\footnotetext{
${ }^{51}$ Debates, XXXIII. 226-227, 351-356, 585.

52 Colony of Natal, Acts of the Parliament of the Colony of Natal, passed in the First Session of the Fourth Colonial Parliament, 1903 (Pietermaritzburg, Times, 1903), pp. 108-124. See Stuart, Zulu Rebellion, chapter III for a review and critique of the Act and the reorganization under it. Sections $80-84$ of the Militia Act provided that the Governor (who was also Supreme Chief) could call out Native, Indian, and coloured contingents, which would form part of the Militia when it was in service, and be utilized as scouts, drivers, \&c, and be armed only in special cases; however, the Regulations contained no provision for such contingents. In 1904 the Imperial authorities fleetingly considered the raising of a permanent Zulu levy, under British officers, but dropped it because the proposition would agitate the settlers - as it had in 1886, 1890 and 1892, and would do so again, especially in present circumstances. (GH 494, pp. 189-192: G713/04, Chief of Gen. Staff, War Office, to Gov., Sept. 1, 1904.)

${ }^{53}$ CR 1902, pp. 1, 3, 4; 1902, p. 1.

${ }^{54}$ CR 1902, p. 7; 1903, p. 34; 1904, p. 39. SYB 1902, p. 212; 1903, p. 256; 1904, p. 252.

${ }^{55}$ CR 1904, p. 3.

${ }^{56}$ Ibid.1903, p. 4. NGG 3368 (Dec. 8, 1903), p. 1727: Volunteer Notice 92 (Nov. 17, 1903); and 337 (Feb. 2 ,
} 
rearmed with Lee-Enfield magazine rifles. ${ }^{57}$ Leader was anxious to increase the number of mobile columns, and mounted corps were organized in the Northern District and Zululand. ${ }^{58}$ He worried about getting good horses, and recommended that the government import Arab stallions from India to breed with horses in the Native Locations, presuming the people there would gladly sell the offspring at reasonable prices. ${ }^{59}$ He was sceptical of townsmen's horsemanship, but authorized mounted companies in the infantry corps. ${ }^{60}$ The field artillery expanded to four batteries, including a section of pompom guns. ${ }^{61}$

The Permanent Staff and Departmental corps at headquarters were augmented, and a Service Corps, a Telegraph Corps and a Veterinary Corps were added. ${ }^{62}$ The Staff was still too small for more than routine tasks and it lacked specialists. ${ }^{63}$ Leader desired that staff officers be sent to England or to India for training - if they could be spared - and that younger officers be exchanged with Imperial ones for two or three years. He believed that trained officers were essential, and in 1903 he held a camp of instruction which was attended by seventy officers and non-commissioned officers, but the course was discontinued in 1904 for want of funds. ${ }^{64}$

The matter of obtaining officers was a sensitive issue. Leader complained of "a want of patriotism” amongst those of the appropriate social status:

\begin{abstract}
It is most unfortunate that so few of the young men of the colony - whose social and financial positions and general abilities point to their suitability for Commissions - come forward to offer their services. It can only be that they do not realise that their first duty as citizens is to take their share of defence. ${ }^{65}$
\end{abstract}

"Patriotism appears better understood" among those in the non-commissioned ranks, he

1904), p. 153: VN 8 (Jan. 25, 1904).

${ }^{57}$ Ibid. 1903, pp. 3, 9.

${ }^{58}$ Ibid and 1904, pp. 12, 39.

${ }^{59}$ Ibid. 1904, pp. 6-7. Bru-de-Wold also recommended this (CR 1906, p. 1035).

${ }^{60}$ CR 1903, p. 3; and 1904, p. 4.

${ }^{61}$ NGG 3407 (Aug. 1, 1904), p. 980: Militia Notice 82/1904 (June 25, 1904); and 3457 (Mar. 14, 1905), p. 390: Militia Order 50 (Mar. 14, 1905).

${ }^{62}$ CR 1903, pp. 1, 3, 34.

${ }^{63}$ Leader complained in March 1904 (CR 1903, p. 8) that the Permanent Staff's time was taken up by routine work, made more burdensome by the large increase in enrolments and the inclusion of the Northern District and Zululand in its range,. There was no one to deal with Intelligence, Mobilization, Operations, Supply and Transport. (Indeed, Dartnell had asked for six years before he was given an office clerk! CR 1893-4: F6.)

${ }^{64}$ CR 1904, p. 5.

${ }^{65}$ Ibid., p. 8. 
observed.

Rifle Associations flourished. There were sixty-eight (with 3,185 members) by the end of 1903, and seventy-six $(3,669)$ at the end of 1904. Leader was anxious to improve marksmanship, and pushed the building of a large new Bisley Range at Mount Rule, outside Pietermaritzburg. Transvaal teams competed with (and lost to) Natal teams, and Natal teams went to English Bisleys. ${ }^{66}$

The School Cadet programme also flourished. There were thirty-two corps with 2,232 boys over ten at the beginning of 1903 , forty with 2,656 at the end of the year. "The progress Natal has made in this matter is being watched with the greatest interest in all parts of the British Empire”, Leader reported. ${ }^{67}$ He believed that training should be compulsory for all boys. A Senior Cadet Corps was established for school leavers who were still too young to join a Volunteer Corps (Leader wanted them to be paid a nominal amount so they would not be "lost" to the Militia). Earl Roberts reviewed the Cadets at the 1904 encampment and commended the Superintendent of Education and Headmasters for their "hearty support" of the movement. A number of corps had mounted drills and trained with Maxim guns, while others received instruction in the work of ambulance, service, and signals corps. New regulations in 1904 provided for the compulsory training of boys under ten and the arming of those over twelve in the state schools. Every private school had its corps. There were forty-four corps - and ten drum and fife bands, five bugle bands, and one pipe band - by the end of $1904 .^{68}$

All this had a price. Defence expenditure rose annually from £298,344 in 1901-1902 to $£ 460,050$ in $1902-1903$; to $£ 460,762$ in $1903-1904$ and $£ 502,845$ in $1904-1905$. Most of the money - about two-thirds of it (four-fifths in 1902-1903) - went to the police, ${ }^{69}$ in which Mansel struggled to maintain the Field Force. However, it demonstrated its usefulness in suppressing disturbances in the South and Umsinga. ${ }^{70}$ The Volunteer Force and Militia

\footnotetext{
${ }^{66}$ Ibid., pp. 3, 4, 5, 7; 1904, p. 41.

${ }^{67}$ Ibid. 1903, p. 6.

${ }^{68}$ Ibid. 1903, pp. 19-20; and 1904, pp. 20-21.

${ }^{69}$ SYB 1902, p. 209; 1903, p. 249; 1904, p. 253; 1905, pp. 7, 249; 1906, p. 65. The amounts are given omitting shillings and pence.

${ }^{70}$ CCP 1902, p. 6; 1903, pp. 3, 20; 1904, pp. 4-5.
} 
annual budgets were £51,306; $£ 71871 ; £ 124,254$, and $£ 145,490$ during this period. $^{71}$ Meanwhile, the Colony’s revenue rose from $£ 3,439,220$ to $£ 4,334,175$ between 1901 and 1903 , fell slightly to $£ 4,150,145$ in $1903-1904$, and fell drastically to $£ 3,384,849$ in 1904 1905. ${ }^{72}$ With this Natal plunged into economic depression. At the end of 1904 the government capped the peacetime establishment of the Active Militia at 3,500 officers and men. Leader did not like the bureaucrats who had been niggling about his office expenditures. ${ }^{73}$ Now he had to shelve plans to establish new units in the countryside and the formation of an Engineer Corps, as well as building operations at the various headquarters. ${ }^{74}$ And nothing at all had been done about the Militia Reserves, which Leader would have liked to organize in connection with the Rifle Associations. ${ }^{75}$

In his (last) annual report for 1904 Leader sounded a warning:

[T]he Defence Forces of the Colony are not in a sufficiently forward state of organisation to justify the economies that have been enforced during the last year, and are contemplated for the coming season.

The Colony is under obligation to put its defences in order. We are without transport, we have not trained Reserves to back up our small Active Force; our Officers are insufficiently trained, and to remedy this some sort of Permanent Training Establishment is required...

If there ever is a time when this Colony can curtail expenditure on defence, it will only be when every man in the Colony has been trained, and when Mobilization stores are complete, but to neglect any preparation at this stage when organisation is just commencing must be to court disaster. $^{76}$

\section{Imperial Intervention}

There was a new outlook in Imperial military circles. The South African War had exposed the military deficiencies of the British Army in modern warfare. A Royal

\footnotetext{
${ }^{71}$ See n. 61. It had been estimated in 1903 that implementation of the new Militia Act would cost £149 047 compared with the Volunteers £76 378. (NGG 3341, Aug. 28, 1903, p. 1144: Return shewing Estimated Expenditure, July 21, 1903.)

72 SYB 1905, p. 7. Meanwhile Ordinary Expenditure went from £3 097601 (1901-1902) to £5 039003 (19021903), £4 071469 (1903-1904) and £3 829588 (1904-1905) (ibid.).

${ }^{73}$ CR 1903, p. 6.

${ }^{74}$ Ibid., pp. 3-4, 5, 6; 1904, pp. 4,7,9.

${ }^{75}$ Ibid. 1903, p. 5. Leader believed that the Militia Reserves should be organized in connection with Rifle Associations, and wanted the rules of the later changed so that they could be ordered to serve outside their districts when necessary. (CR 1903, p. 5.)

${ }^{76}$ CR 1904, p. 4.
} 
Commission investigated its failures in the conduct of the war and reported critically in 1903. A War Office (Reconstitution) Committee reported in 1904, and, as a consequence, the Office of the Commander-in-Chief was abolished and an Army Council was established, with a General Staff in 1904. The object of these reforms was to modernize Army organization and operations. The Staff College adopted a more practical and up-to-date curriculum in 1904, tours of Franco-German war battlefields were resumed and the South African and Russo-Japanese wars were studied. A diplomatic revolution was also under way following Germany's challenge on the High Seas, and in 1902 a Committee of Imperial Defence was established with a view to "the strategic military needs of the Empire", and remodelled with a permanent secretariat in 1904. Thus, the modernizing of Natal's defence system in 1903 did not owe to unique local experience and was not taking place in isolation. ${ }^{77}$

Leader's special concern with Imperial Defence has been noted in respect of Durban harbour. The Natal government was not unaware, of course, of the Colony's unique strategic place in the Empire. Leader typified the post-war outlook of the Army, which was reflected in the importance he attached to trained Staff and the structure of the Militia. He had the sympathy and support of Colonel Sir Henry McCallum, Royal Engineers, who was Governor from 1901 to 1907.

Defence matters were a subject for combined effort on the part of the civil and military authorities. A Colonial Defence Committee had been in existence since 1886, and the first colonial defence scheme had been framed in 1887, and been revised continually thereafter. ${ }^{78}$ In 1897 the plan integrated Imperial and Colonial forces with a view to the forthcoming war. ${ }^{79}$ The Militia Act provided that the Governor-in-Council could appoint a Committee of Defence for the purpose of advising him on all matters of defence. Members held office at his pleasure. The committee in 1903 comprised of three Imperial officers stationed in Natal (those commanding troops, artillery, and engineers), as well as a naval officer; the Commandant of Militia (also an Imperial officer); the Commissioner of Police;

\footnotetext{
${ }^{77}$ See Brian Bond, The Victorian Army and the Staff College 1854-1914 (London, Eyre Methuen, 1972), pp. 189-199, 213-230, 334-335; C. E. Carrington, The British Overseas: Exploits of a Nation of Shopkeepers (Cambridge University Press, 1950), pp. 856-859; Ronald Hyam, Britain’s Imperial Century, 1815-1914: A Study of Empire and Expansion (2 ${ }^{\text {nd }}$ edition; London, Macmillan, 1993), pp. 259-262; and David Killingray, "Imperial Defence", in The Oxford History of the British Empire, Volume V. Historiography (edited by Robin W. Winks; Oxford University Press, 1999), pp. 34-345.

${ }^{78}$ See the lists of Colonial Defence Committee documents, dated March 8, 1905, in GH 510, pp. 165-171 (G179/1905).

${ }^{79}$ GH 541: G156a/1897, General Officer Commanding to Gov., Apr. 21, 1897.
} 
two Militia officers; and two members of parliament. This arrangement remained until $1905,{ }^{80}$ but then the withdrawal of Imperial troops from the garrison reduced the number of Imperial officers and gave the Colonials preponderance. ${ }^{81}$

This symbiosis of Imperial and Colonial military produced a new spirit and a distinct improvement in the organization of local defence, but the Imperial factor had another aspect, which put great strain on the relationship in Natal. This was the demand on the part of the Army Council for combined planning, unity of command in combined operations, and colonial compliance with Imperial standards.

Leader held the regimental rank of major, but he had been brevetted to colonel for his service in the field, and was given the local rank of brigadier-general in 1904. Even so the Militia Act stated that only an Imperial officer with the rank of major-general could command the Militia if it were called into Imperial service. There were only two majorgenerals in South Africa, and neither of them could be spared from their present duties. The Governor therefore informed the Minister of Defence that the Imperial authorities could not send troops to Natal to quell a disturbance, because they could not control the Natal Militia, and a divided command would be fatal to operations. Natal would have to look after itself. The Natal government responded by passing a bill which changed the rank from majorgeneral to colonel, as indeed it had been under the old Volunteer Act. ${ }^{82}$

The prospect of withdrawal of the Imperial garrison was constantly held up to Natal as an inducement to complete the organization of the Militia system as soon as possible. In May 1904 the Imperial forces in South Africa were reorganized. Natal ceased to be a separate military district and was consolidated with Harrismith in a sub-district, with headquarters in Harrismith. The office of the officer commanding troops in Pietermaritzburg was closed in August. ${ }^{83}$ The Chief of the General Staff at the War Office wrote to the Governor in August 1904 that the opinion there was that if Natal wanted Imperial troops to

\footnotetext{
${ }^{80}$ Natal Civil Service List, 1903, p. 168; 1904, p. 171; 1905, p. 176.

${ }^{81}$ GH 513, p. 98: G836/05: GOC to Gov., Oct. 14, 1905. To date I have not been able to find the records of the Defence Committee.

${ }^{82}$ GH 512, pp. 141-144: G735/04, GOC to Gov., Oct. 15, 1904 and reply Oct. 25, 1904; 542, pp. 55-59: G682/04, correspondence Oct. 11-Nov. 11, 1904.

${ }^{83}$ Or possibly in September. GH 506, p. 5: G367/04, GOC to Gov., May 13, 1904; 551, pp. 158-161: OC to Administrator, July 22, Aug. 3, Sept. 9, 1904. Cf 1283, p. 20: Gov. to S/S, Feb. 4, 1905.
} 
remain then Natal should pay the cost of keeping them there. ${ }^{84}$

Meanwhile the Imperial garrison shrank, from two mounted regiments and three of foot, a field artillery brigade, and a company of engineers in 1903, to a battalion of infantry and a field artillery brigade in $1905 .^{85}$ At the end of the year "a mere handful of men remained”. ${ }^{86}$ In January 1905, the General Officer Commanding agreed to leave the $1^{\text {st }}$ Battalion of the Royal Garrison Regiment with about 200 men at Fort Napier; but it was so reduced in 1905 that in November it could no longer provide a sentry for Government House and the Natal Police had to do so. ${ }^{87}$

Then there was the Natal Defence Scheme. In 1903 the War Office in London required Major-General Sir Henry J.T. Hildyard, the General Officer Commanding His Majesty's forces in South Africa, to produce a defence scheme for the event of a Boer uprising. It was not that an uprising was actually expected, the Chief Staff Officer in Pretoria explained to the Officer Commanding Sub District Natal, but it was "in accordance with the customs of the service wherever troops are stationed" ${ }^{88}$ The local commander passed the order on to the Commandant (and of course the Governor), and together they put together a Mobilization Scheme and submitted it in May 1904. In an emergency the Natal Militia and Rifle Associations could secure the vital railway line from Durban to the Reef and little else. $^{89}$

There were reports of trouble in Zululand in 1903, centring on the former king, Dinuzulu. The Natal Defence Scheme did acknowledge the possibility of a Native complication to a Boer uprising, but the Prime Minister dismissed the prospect of a Zulu uprising in June 1904. The next month the General Officer asked for a Mobilization Scheme to deal with one, and in December one was submitted. The Active Militia would invade Zululand from Greytown and the Lower Thukela, but Imperial forces would assist it in the

\footnotetext{
${ }^{84}$ GH 495, pp. 2-8: G275/04, CGS to Gov., Aug. 16 and 28, 1905.

${ }^{85}$ See the annual Natal Almanac Directory and Yearly Register (Pietermaritzburg, Davis) for 1903, pp. 326-327; 1904, pp. 325-326; and 1905, p. 242.

${ }^{86}$ Stuart, Zulu Rebellion, p. 63.

${ }^{87}$ GH 512, pp. 162-163: G260/05, GOC to Gov., Aug. 15, 1905; 516, p. 47: G952/05, Gov. to Min. of Just., Jan. 6, 1905; pp. 56-58: G158, GOC to Gov., Feb. 21, 1905. See also correspondence in 553, pp. 66-77: G873/05.

${ }^{88}$ GH 511, pp. 13-15: G205/1905, Chief Staff Officer, S. A., to GOC, Natal, Jan. 2, 1904.

${ }^{89}$ See the correspondence in ibid., pp. 2-84. There is a typescript copy of the scheme on pp. 58-84.
} 
Northern District. $^{90}$

The preparation of the Mobilization Schemes - or the Natal Defence Scheme as they became collectively and interchangeably to be called - laid a heavy additional burden on the staffs of the Militia and the Imperial garrison. Naturally they were imperfect in many details, and Army Headquarters in Pretoria wanted clarifications and corrections. Thus the schemes were not really complete when Natal was overtaken by the Zulu Rebellion in $1906 .{ }^{91}$ Worse, they seem to have strained relations between the Imperial and Colonial authorities, who did not see eye to eye on the need for improvements.

The differences brought the Governor and his Ministers into confrontation early in 1905. The Governor had pressed the Imperial authorities, who agreed to keep the garrison in Natal, and the Natal government apparently understood that it should complete the Colony's defence arrangements to their satisfaction; however, the government in Natal changed three times between 1903 and 1905, ${ }^{92}$ and Ministries suffered short-term memory problems with their predecessors’ undertakings on defence.

Perusal of the Mobilization Schemes revealed two weaknesses which, in the opinion of the General and the Governor, had to be rectified. The defence arrangements could not be considered complete until they were. The Natal government did not agree and declined to act, or at least to act timeously.

The first of the two weaknesses was inadequate provision for transport and reserves.

There had to be transport - animals, wagons, equipment - to hand to move the troops, especially First Line Transport to accompany the Active Militia in initial operations. Yet the Act provided nothing. In an emergency martial law would be proclaimed and what was

\footnotetext{
${ }^{90}$ See correspondence and reports in GH 542: G507, 644, 799, and 803/1904. There is a typescript copy of the scheme in G799, pp. 95-109.

${ }^{91}$ See later correspondence in the Minutes cited above.

${ }^{92}$ George M. Sutton succeeded Sir Albert Hime as Prime Minister in August 1903, followed by Charles J. Smythe in May 1905 and Frederick R. Moor in November 1906. Thomas Watt was Minister of Defence in Sutton's and Smythe's cabinets, and W.A Deane was Minister in Moor's. "The absence of strict party divisions in the Natal Parliament meant that changes of ministry occurred frequently owing to personal issues, or the illhealth of the Prime Minister, and had no great political significance." (Brookes and Webb, History of Natal, p. 212.)
} 
needed, if it could not be bought at once, would have to be commandeered. Imperial officers - Governor, General, Commandant - foresaw confusion and disaster in this event. They wanted a requisition plan in advance, so that Militia and Transport would come together at the same time and take the field without mishap.

The other weakness was the lack of Militia Reserves, especially the First Reserves of young, able-bodied men. The Act provided for their organization and the election of leaders, but for peacetime training. It might be that training as Cadets or previous service in the war or in the Active Militia or practice in the Rifle Associations would stand some of the men in good stead in an emergency, but even so they were not organized yet, and ad hoc units would lack discipline and cohesion. Again, the Imperial officers foresaw confusion and disaster.

The government recognized the weaknesses, but thought the military exaggerated them. The Militia Act was muted on them because the bill to reform might have been lost if they had amplified their concerns. There still was opposition. Most of it seems to have been upcountry, especially in the Northern District, where there was a strong Boer element. Now there was a problem of cost, which the Colony could ill afford.

In March, General Hildyard wrote to the Governor that the defence schemes of the other colonies in South Africa were practically complete. The Natal scheme had been referred for revision, but the Natal Defence Committee apparently did not think it needed to be revised. Sir Henry decided to bring the weight of his office to bear on the government. He warned the Prime Minister that he would have to inform His Majesty's government that his Ministers refused to provide the "absolute essentials" of defence, and therefore Imperial forces must be withdrawn from the Colony. The government would not budge. The Commandant provided two reports for the organization of transport. The General warned that the Natal Militia was of great importance to the defence of all South Africa. At the beginning of April, the Governor informed his Ministers that he was going to lay the complete correspondence with them before the General for the information of His Majesty's government. "I concluded the same minute by warning them that by inaction and incompletion they were courting disaster in the event of a serious uprising.”

The government yielded on transport. At the end of the month the General visited the 
Governor in Pietermaritzburg, and they haled the Prime Minister and the Minister of Defence (who was out of town, but another stood in for him) to a meeting on the $29^{\text {th }}$. Together they thrashed out Colonial preparedness. The two Ministers said they were having trouble with parliament. The best they could do was to push through legislation on transport now, and leave Reserves until the next session. The General said he thought the garrison could be kept another two years, while the organization of defence was completed. The Governor was satisfied he had got the best he could in the circumstances. ${ }^{93}$

The financial crisis brought an election and another change of government in May 1905, but the new one honoured the agreement with Governor and General, and at last things began to move. In July the Militia Act was amended to enable the Commandant to prepare a register of all animals and vehicles suitable for transport, and, when the militia was called out, to requisition them (up to half of what an owner had). ${ }^{94}$

The government considered it impolitic to propose an amendment for the organization of the Reserves, and denied an undertaking on that point, whereupon the Governor produced two years correspondence, and the Ministers backed down. ${ }^{95}$ In November, the government published notices of meetings in the northern part of the Colony for the election of officers in December and January. There were delays, and the meetings took place in January and February, but at least the first step was being taken. ${ }^{96}$

\section{The Colonial Commandant}

The Governor and General at last got their way with reserves and transport, but not with the command of the militia. Against their wishes the government appointed as Commandant a Colonial officer, not an Imperial one.

Leader's regiment had been transferred to India, and he wished to rejoin it and take command. The Natal government, one may imagine, had had enough of Imperial officers

\footnotetext{
93 See the Governor's summary of events in GH 1283, pp. 45-49: Gov. to S/S, May 5, 1905; and other correspondence in 542, pp. 79-87, 115-121: G799/04.

${ }^{94}$ NGG 3491 (Aug. 22, 1905), p. 1522: Act 30 of 1905 (Aug. 18, 1905).

${ }^{95}$ See correspondence in GH 542, pp. 78-87: G799/1904.

${ }^{96}$ NGG 3505 (Nov. 21, 1905), pp. 1904-1905 and 1964 and 2031: Militia Notices Nov. 16, and Dec. 4 and 23 , 1905, respectively; and p. 2025: GN 812/05 (Dec. 21, 1905). GH 542, p. 117: Gov. to GOC, Nov. $10,1905$.
} 
telling them what to do. In any case, it did not approach the Governor about the appointment of Leader's successor; but the General Officer Commanding forwarded applications of three Imperial officers, stating which one he preferred, and the Governor passed them on to the Prime Minister. He also stated his opinion that to appoint a Colonial Militia officer as Commandant would be a mistake, since such an officer would lack professional qualifications for the position, be accused of partiality towards his old unit, and become "the creature of the Ministry of the day, liable to instant dismissal if he did not make his mind coincide with that of the Minister". ${ }^{97}$ The government changed and the matter dragged on. At the beginning of July Colonel Bru-de-Wold, District Commandant in the South, was appointed acting Commandant. In August, Leader asked the General who would replace him. He issued a "farewell order" on September $19^{\text {th }}$. Bru-de-Wold was appointed only on October $5^{\text {th }}$, and took office on the $15^{\text {th }} \cdot{ }^{98}$ The Governor wrote to the General that the government had made a mistake and the appointment was "a retrograde step". 99

The General expressed his concern that there was no Imperial staff officer in Natal. Those with the garrison at Fort Napier did not have the special training to qualify them to advise the Defence Committee. He asked the Governor to urge the Ministers to appoint an Imperial officer to the staff of the Commandant or to be the secretary of the committee. The Governor did so. The Minister of Defence replied that there was no vacancy on the staff, but if one occurred they would consider such an appointment. ${ }^{100}$

Lieutenant-Colonel Bru-de-Wold was the commanding officer of the Border Mounted Rifles and the District Commandant for southern Natal. A Norwegian immigrant in 1862, he had begun his career in the Colony as a labourer and he ended it as a coffee planter. He had begun his military career in the Volunteers in 1866, had risen from the ranks to officer and served in the Anglo-Zulu and South African wars - in the latter he had received a severe face wound. He had served on the Defence Commission in 1902 and then on the Defence

\footnotetext{
${ }^{97}$ GH 512, pp. 145-1446, 149-150, 160-163: G260/1905, GOC to Gov., Mar. 30 and Aug. 15, 1905; Gov. to PM, Apr. 3, 1905, respectively; and 525, p. 57: G313/05, CSO to Gov., May 14, 1905.

${ }^{98}$ Ibid. GOC to Gov., Aug. 15, 1905. NGG 3494 (Sept. 12, 1905), p. 1663; 3495 (Sept. 19, 1905) p. 1666; 3501 (Oct. 31, 1905), p. 1815: Militia Orders 157 (Sept. 12, 1905), 167 (Sept. 19, 1905) and 192 (Oct. 31, 1905).

${ }^{99}$ GH 512,: G260/1905, Gov. to GOC, Oct. 9, 1905. Returning the papers to the Governor, the Prime Minister remarked that, with respect to their alleged mistake, the Ministers "regret the expression of Your Excellency's view", to which the Governor replied: "I equally regret the necessity of expressing a view which differs from those of Ministers". (Ibid., p. 148: Oct. 13, and 20, respectively.)

${ }^{100}$ Ibid. 513, pp. 98 -100: G836/05, GOC to Gov., Oct. 14, 1905, and reply Oct. 26, 1905; Min. of Def. to Gov., Oct. 24, 1905.
} 
Committee. There was no doubt about his diligence, energy and intelligence, but there was no denying that his experience had been confined to Natal and he lacked the professional qualifications of a regular officer. ${ }^{101}$

There were other important differences between Bru-de-Wold and Leader, reflecting very different backgrounds. Bru-de-Wold was not obsessed with a large and variegated Permanent Staff, and he did not like the system of District Commandants. He recognized the need to organize transport and reserves, but he had nothing to say about the Imperial Reserves or a Native Corps of which Leader spoke. But the most significant difference was in outlook. Leader thought in terms of Empire, Bru-de-Wold in terms of Natal:

\begin{abstract}
The man who is content to leave the defence of his country, and family, to hired mercenaries, is not a desirable citizen of any country, and must be utterly ignorant of South African history and South African Native Wars. [...]
\end{abstract}

\begin{abstract}
It is essential that a highly-trained and mobile force should be in existence, lightly equipped with the minimum of transport, to patrol the country, particularly the large Native Locations, appearing and disappearing suddenly, and showing the Native, who is the only enemy we contemplate, that there is a force of the Government ever on the alert. ${ }^{102}$
\end{abstract}

Bru-de-Wold's position was unenviable. The Colony was still very much a frontier settlement, and the position of the settlers was precarious. ${ }^{103}$ The government provided $£ 453,122$ for defence in the 1905-1906 budget, of which the Militia’s share was $£ 118,558^{104}$ $-25 \%$ less than the previous year. Bru-de-Wold was ordered to stop recruiting and reduce the Active Militia from 3,335 to 2,500 officers and men. ${ }^{105}$ The Active Militia was not reduced instantly, of course, but Bru-de-Wold could not put off the process. When Army Headquarters asked about progress with the Defence Scheme, he answered that it would now have to be considerably revised and in effect he had not the time or staff to do it just then, and deferred to the less than effectual Defence Committee. ${ }^{106}$ Departmental corps were stunted, just when Bru-de-Wold would have liked to increase them by 500. He could not afford an

\footnotetext{
${ }^{101}$ Natal Civil List 1906, p. 196. H.C. Lugg, Historic Natal and Zululand (Pietermaritzburg, Shuter \& Shooter, 1949), p. 1. Stuart, Zulu Rebellion, pp. 46n and 48. Goetzsche, “Rough but Ready,” p. 45.

102 Bru-de-Wold in CR 1906, pp. 1038 and 1037, respectively.

103 According to the 1905 Census there were 97109 Europeans, 100918 Asiatics, 903041 Natives, and 6686 Mixed and Others.(SYB 1904, p. 3). 102494 Europeans lived in the five towns (p. 14).

${ }^{104}$ SYB 1906, p. 65.

105 Ibid. 1905, p. 68. CR 1906, p. 1033.

${ }^{106}$ See the correspondence in GH511, pp. 2-9: G205/1904, and GH 542, pp. 18-27: G644/1904.
} 
Intelligence corps, and once again the creation of an Engineer corps was put off. ${ }^{107}$

Yet, Bru-de-Wold was a driven man. He was convinced, partly from his own experience in the turbulent south of Natal and partly by recent confidential reports from various quarters, that a Native rising was imminent. He thought it would occur in late May or June of 1906. He did his best to prepare for it. He reduced his staff by one officer, but did away with the District Commandants and centralized functions at headquarters. He called the corps commanders to headquarters and discussed reduction to a peacetime establishment in terms of the budget, and got them to agree to a plan to expand in an emergency by drawing on supernumeraries and special servicemen. He also set about organizing the Reserves, attending several meetings and then turning the task over to Colonel Wales and the magistrates. The Departmental corps, such as they, were made ready for the field. The registration of transport was begun, and the government was persuaded to allow orders for additional arms, ammunition and equipment. ${ }^{108}$

The Zulu Rebellion ${ }^{109}$

The Native Rebellion which Bru-de-Wold anticipated occurred as a result of violent protests against the government's imposition of a poll tax - an ill-conceived measure to rescue the Colony from its debts. A clash between protesters and police occurred near Richmond on February $8^{\text {th }}$.

On February 9, 1906 the Governor proclaimed martial law in the Colony, and authorized the Commandant to call out the Active Militia for service. Colonel Bru-de-Wold at once ordered the Natal Carbineers, C Battery of the Natal Field Artillery, and detachments

\footnotetext{
${ }^{107}$ CR 1906, pp. 1033, 1035, 1036.

108 CR 1906, pp.1033-1034. Archives of the Colonial Secretary’s Office (hereafter cited as CSO). 2599: C147/1906, INTERIM REPORT By Commandant of Militia Natal on THE NATIVE REBELLION, 1906 (hereafter cited as IR), pp. 1-2. See also Stuart, Zulu Rebellion, p. 48.

109 The account here follows IR in its sequence of events, but is also based on other works which deal largely with the military aspects of the rebellion, viz. Stuart, Zulu Rebellion; Walter Bosman, The Natal Rebellion of 1906 (London, Longmans, Green, 1907) and P.S. Thompson, An Historical Atlas of the Zulu Rebellion of 1906 (Pietermaritzburg, private, 2001). Also with IR in CSO 2599: C147/1906 are the reports of the independent column commanders, notably McKenzie, Leuchars, Mackay, and Mansel, as well as Special Service (Irregular) and Departmental officers. Stuart's and Thompson's narratives are based on these reports. The violence in Natal and Zululand in 1906 has been variously described in the literature as a rebellion, insurrection, rising or uprising, disturbance(s) and isidumo, and been called the Zulu Rebellion, the Natal Rebellion, the Natal Native Rebellion, the Bhambatha Rebellion or Bhambatha's Rebellion. I prefer the term Zulu Rebellion for its comprehensiveness.
} 
of Departmental corps to mobilize at Pietermaritzburg. The Natal Police Field Force and later part of the Border Mounted Rifles were attached to the column, which was placed under the command of Colonel Duncan McKenzie of the Carbineers. All other corps were alerted to make arrangements; also the Natal Government Railways, and transport arrangements were put into effect. ${ }^{110}$ A battalion of Imperial troops was sent from the Transvaal to Natal to show that Britain supported its Colony, but it did not leave Fort Napier. ${ }^{111}$

McKenzie was given a free hand to scour the Richmond district and punish the rebels who had attacked the police, which he did, and then his Field Force moved on to Ixopo and Umzinto and overawed restless tribes in the south of the Colony. Meanwhile, other corps were mobilized under Colonel George Leuchars of the Umvoti Mounted Rifles and took the field for the same purpose in Mapumulo. Both field forces were demobilized in late March. Leuchars made arrests and destroyed a chief's kraal with artillery fire. ${ }^{112}$ McKenzie also made arrests, and laid on court martials which sentenced the ringleaders of the unrest to death. The Governor quickly intervened to commute the sentences. As a result, McKenzie tendered his resignation in protest, but it was refused. The original rebel band which had attacked the police in February was caught, tried, sentenced and executed. The British government tried to intervene, which created a political furore, and it backed off and let the executions take place. ${ }^{113}$

Early in April a deposed chief in Umvoti named Bhambatha tried to retrieve his chieftaincy. He and his followers attacked the magistrate and then the police. The local Militia were remobilized under Leuchars, but the rebels escaped to Zululand, where several tribes joined them. ${ }^{114}$

Thus began the Zulu Rebellion of 1906, which took many turns and lasted three months (five, if mopping-up operations are counted). In April and May the Colony of Natal

\footnotetext{
${ }^{110}$ IR, pp. 2-3.

${ }^{111}$ Bosman, Natal Rebellion, p. 3. Colony of Natal, The Natal Native Rebellion as told in Official Despatches From January $1^{\text {st }}$ to June $23^{\text {rd }} 1906$ (Pietermaritzburg, Davis, 1906), pp. 18 and 32, Gov. to Secretary of State, Feb. 16 and Mar. 2, 1906, respectively.

112 IR, pp. 4-9A. Bosman, Natal Rebellion, pp. 5-17.

113 Shula Marks, Reluctant Rebellion: The 1906-1908 Disturbances in Natal (Oxford, Clarendon, 1970), pp.189195. Stuart, Zulu Rebellion, pp. 141-147. Thompson, Historical Atlas, pp. 14-15, and Incident at Trewirgie: First Shots of the Zulu Rebellion 1906 (Pietermaritzburg, private, 2005), pp. 51-58.

114 IR, pp. 9A-11. Stuart, Zulu Rebellion, pp. 167-203 passim. Bosman, Natal Rebellion, pp. 18-25. P. S. Thompson, Bambatha at Mpanza: The Making of a Rebel (Pietermaritzburg, private, 2004), pp. 87-118.
} 
had a full blown crisis and its capacity for self-defence was strained beyond its power. What is of concern here is the government's military initiatives, especially of a strategic nature, which reveal the efficacy (or not) of the Militia organization. The government knew that the rebellion must be crushed as soon as possible in order to minimize costs and interventions, and, of course, to prevent its spread. The rebels, in so far as they were armed and in the field, were confined to the Nkandhla Division of Zululand, but they had many sympathizers all around and further afield. It was necessary to take these into account, too. Dinuzulu, whatever his real intentions, publicly supported the government against the rebels. The Zululand Mobilization Scheme of 1904 became irrelevant.

In the first instance, the government was guided by the counsels of the Commissioner for Native Affairs in Zululand, Charles Saunders, who wished to avoid bloodshed and tried to negotiate with the rebel chief Sigananda. Thus Leuchars' field force remained on the defensive in Natal, and the Zululand Mounted Rifles and the Natal Police Field Force secured the Commissioner's position at the Nkandhla magistracy. Negotiations failed and Saunders panicked; both he and Mansel (who was in charge of the forces at the magistracy) urged that Imperial forces be called in, but the government refused until it could be shown that Natal forces could not suppress the rebellion.

On April $17^{\text {th }}$ the Ministers met to discuss the crisis. Bru-de-Wold, Leuchars and McKenzie were in attendance. It was decided that a strong mounted force with ample supplies should be sent to Nkandhla; however, Natal should not be denuded of all of its Active Militia lest this encourage rebellion there. Therefore, Irregular corps must be raised to operate in Zululand, and one, of 600 mounted men under command of Lieutenant-Colonel J.R. Royston of the Border Mounted Rifles, was authorized. Bru-de-Wold's plan was to draw a cordon of posts manned by Militia (including some of the Reserves which had just been organized) around the rebel stronghold and then to send in strong forces to strike the rebels. During the next few weeks Bru-de-Wold applied himself to this. Meanwhile, the Transvaal government offered gratis the assistance of a mounted corps, which the Natal government gratefully accepted, and Bru-de-Wold brigaded it with Royston's Horse and a few bits and pieces of Active Militia to form the Zululand Field Force, under the command of Colonel McKenzie. By early May there were almost 4,000 troops in the field. 
The Zululand Field Force, with a large train of supplies, marched via Dundee to Nkandhla. Saunders did not think this was enough, and the government raised another Irregular corps, the Natal Rangers. It was infantry - which was more suitable for garrisons along the lines of communication and just as useful as dismounted mounted men were in the Nkandhla forest. Also, horses were in short supply, as the government found when it also authorized the raising of a corps of Natal Native Horse. Saunders reported that the rebellion seemed to be spreading. So the government decided to raise the mounted corps of the Active Militia to war strength. Another large convoy was despatched under escort to the beleaguered magistracy. ${ }^{115}$

Disaffection in Umsinga had led to the establishment of a small field force at Helpmekaar in late April, which was augmented in early May. There were skirmishes and the rebels fled to Zululand. Colonel Mackay, with the Natal Carbineers, and an assortment of other Militia was to secure this area, but when the Zulu chief Mehlokazulu rebelled, he disobeyed orders and took the Carbineers across the border after him. Leuchars tried to help, crossed into Zululand and defeated part of Mehlokazulu's force in a sharp battle at Mpukunyoni. Thereafter, Mackay conducted a leisurely advance into Nkandhla, looting many cattle but letting the rebels escape to Qudeni. Bru-de-Wold's patience was wearing thin, and Umsinga was added to Leuchars' command. At the end of May there were more rebels in the field than ever before. ${ }^{116}$

Bru-de-Wold's strategy apparently was not working. Leuchars was guarding the Thukela border against the rebels breaking back into Natal, Mackay was doing more or less as he pleased in Nqutu, and McKenzie was striking hard in Nkandhla but missing the rebels every time. It was at this juncture that Sir Henry McCallum decided to bring a governor's weight to bear again. Through Bru-de-Wold, he instructed McKenzie to change his tactics that was to drive the forests to flush out the elusive enemy and destroy his resources. ${ }^{117}$ Brude-Wold's health gave way, and he was ordered to take sick leave. Sir John Dartnell, who was visiting Natal to bring some Rexer guns, which were new weapons that some Natalians

\footnotetext{
115 IR, pp. 13-21. Stuart, Zulu Rebellion, pp. 211-228. Bosman, Natal Rebellion, pp. 27-39. Thompson, Historical Atlas, pp. 16-17.

${ }^{116}$ IR , pp. 21-22. and see Leuchars' and Mackay’s reports, also in CSO 2599: C147/1906. Stuart, Zulu Rebellion, pp. 318-332. Thompson, Historical Atlas, pp. 24-29.

117 Natal Native Rebellion, pp. 123 and 129: Gov. to S/S, June 1, and Cdt. to OC ZFF, May 28, 1906, respectively.
} 
living in London had bought as a gift to the Militia, was appointed acting Commandant. ${ }^{118}$

There was another meeting of Ministers and commanders on June $6^{\text {th }}$ and $7^{\text {th }}$, and it was decided to augment the Natal Rangers and Royston's Horse, to accept the Cape Colony’s offer of a Maxim battery, and to ask it for a signals company. A Transvaal magnate supplied another infantry battalion. ${ }^{119}$

Meanwhile, McKenzie drove the Nkandhla forest until he felt the rebels had gone, and then turned to the combined rebel forces at Qudeni. Intelligence revealed that the rebel army was moving eastward, and he was determined to intercept it. For once things went right for McKenzie, and he practically destroyed the rebel impi at the mouth of the Mome gorge on June $10^{\text {th }}$. Thus organized resistance ceased in Nkandhla. McKenzie was quick to follow up his victory, and the rebellion in Zululand collapsed. ${ }^{120}$

The outbreak of the rebellion in Mapumulo in mid-June was a contretemps which has never been satisfactorily explained. The rebels had none of the advantages of those in Nkandhla. The Zululand and Umvoti Field Forces moved speedily to Mapumulo and destroyed the rebel forces with much bloodshed and destruction of property. The Militia was demobilized and the Irregular corps disbanded by the end of July, except Royston's, which made a thorough search of Nkandhla in August, and several small composite corps remained in the field to mop up and police until early September. Martial law was lifted on October $2^{\text {nd }} \cdot 121$

The rebellion was over. The government had fielded more than 9,000 troops (and 5,000 Native levies) in the rebellion, but casualties were small - Active Militia: six killed and nine wounded, Militia Reserves: one killed and four wounded, Natal Police: six killed and six wounded, Irregular corps: seventeen killed and eighteen wounded, and Native levies: six

\footnotetext{
${ }^{118}$ IR, p. 23. Natal Native Rebellion, p. 159: Gov. to S/S, June 8, 1906. Stuart, Zulu Rebellion, pp. 65, 285.

${ }^{119}$ IR, p. 24. Stuart, Zulu Rebellion, pp. 223, 329.

${ }^{120}$ IR, p. 26. Stuart, Zulu Rebellion, pp. 295-317, 333-338. Bosman, Natal Rebellion, pp. 65-108. Thompson, Historical Atlas, pp. 36-41.

${ }^{121}$ IR, pp. 26-31. Stuart, Zulu Rebellion, pp.343-405. Bosman, Natal Rebellion, pp. 119-165. Thompson, Historical Atlas, pp. 42-61. See also Jeff Guy, The Maphumulo uprising: War, law and ritual in the Zulu rebellion (Pietermaritzburg, University of KwaZulu-Natal Press, 2005). The Native levies, which were attached to Militia columns, retained their tribal organization and traditional methods of warfare. See John Laband and Paul Thompson, "African levies in Natal and Zululand, 1839-1906," in Soldiers and Settlers in Africa 18501918 (edited by Stephen M. Miller; Leyden, Brill, 2002), pp. 49-84).
} 
killed and about thirty wounded. ${ }^{122}$ The cost was $£ 676,613 .{ }^{123}$

\section{Lessons of the Rebellion}

Bru-de-Wold returned to duty when the rebellion was almost over, and subsequently wrote two reports. The first focussed on military operations and concluded with comments on the Militia's performance in the field. The comments generally were echoed in the reports of Colonel McKenzie on the field forces' operations and of the Imperial observer, MajorGeneral F.E. Stephenson, who spent several weeks with the Zululand Field Force. Bru-deWold's second report (the Commandant's annual one) repeated much that he had said about performance in the field, but focussed on the organization of the Militia and made recommendations for its improvement. ${ }^{124}$

Staff work had been good, although this owed in part to supernumeraries coming forward to do much of it. The Departmental corps functioned very well, and an Intelligence section had been improvised. Mobilization had gone very well thanks, in part, to full cooperation of the Natal Government Railways, and, in part, to the Transport officer's planning and organization in the short time before the rebellion. The government's Auditor General helped materially by cutting through much paper work. Nonetheless, some of the problems which had been forecast occurred. The most apparent being that the forces needed pack horses in the first instance and mules in the First Line. The use of oxen had generally slowed and sometimes prevented important movements in the field.

The Mounted Rifles were the backbone of the defence force, and all the corps had performed well; however, the operations in rugged Nkandhla had taken a heavy toll of horses and it was not easy to get remounts. In the first month the government bought up all the extra horses in the Colony; in a few more months all those in the neighbouring colonies, and finally it had to import ones (some of them unbroken) from South America. Infantry worked well driving the forest, but artillery moved with difficulty and found few targets. Bru-de-Wold suggested more use of infantry, if mule transport moved them from point to point, and the

\footnotetext{
${ }^{122}$ Stuart, Zulu Rebellion, pp. 522, 540-542.

123 SYB 1906, p. 156. Cf Stuart, Zulu Rebellion, p. 406.

${ }^{124}$ Bru-de-Wold's reports have been cited above as IR and CR 1906, respectively. McKenzie's report is with IR in CSO 2599: C147/1906. Stephenson's report is GH 569, pp. 147-163: G585/1906.
} 
replacement of one field artillery battery with a mountain battery.

He was pleased with the work of the Militia Reserves, which had been organized in the magisterial divisions bordering Zululand. On occasions, they had reinforced the Active Militia and even been engaged in the field, notably in Umvoti and Krantzkop divisions. ${ }^{125}$ Elsewhere, they gave a sense of security to the people, settlers and Natives alike, in disturbed areas. During the rebellion, Colonel Wales met with chiefs in Pietermaritzburg to draft regulations, and parliament amended the Militia Act so that the Commandant could call up Reserves for training. Bru-de-Wold speculated that the First Reserves might become part of the Active Militia corps, adding their cadres and trained men to expand the latter when the need arose.

The number of Rifle Associations increased from 89 to 117 in 1906, and membership (less police and militia) increased from 3,004 to 5,774. ${ }^{126}$ Bru-de-Wold valued them for shooting practice rather than defence, because the men would now be drawn into the Reserves. He speculated on their future:

[...]They are now really Government Aided Rifle Clubs, somewhat on the same lines as Government Aided Libraries or Book Clubs, and I therefore consider, as I have stated in other papers, that ladies should be allowed to join these Clubs or Associations on the same terms and conditions as men. It would be of the greatest advantage if the women of the Colony, particularly in country districts, would take up rifle shooting as a recreation. It would encourage the young men to become [better] rifle shots, and, in times of Native unrest, would be of inestimable value, in giving the ladies more self-reliance, infusing confidence, while if the homestead should be attacked, there would be so many more rifles to defend it. It is well known that the Native has a wholesome dread, and fear engenders respect, of a woman who can use a firearm. ${ }^{127}$

\section{The Active Militia reduced and streamlined}

The Militia had performed well in the field, but it was obvious that reinforcements from outside the Colony had been needed to quell the rebellion. Yet, with the passing of the crisis in 1906 the Active Militia was again subject to reduction to a peacetime strength of 2,500. It numbered 2,739 at the end of 1907; 2,432 at the end of 1908, and 2,580 at the end

\footnotetext{
${ }^{125}$ Mackay dissented, saying that most were "simply a rabble” (report, in CSO 2599: C147/1906).

${ }^{126}$ SYB 1906, p. 65. (CR 1906, p. 1038, gives 117, SYB 119.)

${ }^{127}$ CR 1906, p. 1038.
} 
of 1909 - the slight increase owed to additional Departmental corps. ${ }^{128}$ McKenzie, who was acting Commandant vice Bru-de-Wold (who was on leave from February 1907) and then Commandant from August, deplored this reduction, ${ }^{129}$ and stated that the Colony's defence force was insufficient to protect the Colony and maintain law and order. ${ }^{130}$ The mounted regiments consisted of skeleton squadrons and troops, which made training in country districts very difficult. ${ }^{131}$ In 1907, he recommended the formation of Military Districts and Regimental Recruiting Areas with a view to making units more "compact” and efficient. ${ }^{132}$

For all this the government continued to economize. Defence spending was cut to $£ 371,001$ in 1907-1908 and to £332,088 in 1908-1909, exclusive of contributions to Royal Navy $(£ 35,000)$ and customs rebates for the Imperial forces (£3,940 and $£ 3,925)$. $£ 54,839$ was spent on the Active Militia and £2,386 on arms and ammunition in 1907-1908 (including the Zululand expedition) and only £39,361 and £206 in 1908-1909. ${ }^{133}$

There was no need of an annual encampment in 1907 because of the practical experience in 1906, ${ }^{134}$ but financial constraints prevented any in 1908. Quarterly parades continued, but men were not paid to attend them; the Commandant wanted firing practice to continue, and so allowances were provided for ammunition. ${ }^{135}$ When encampments resumed in 1909, attendance was voluntary and required for only two days, and the Commandant observed that a number of young men lacked proficiency. ${ }^{136}$ Attendance was set at seven days in 1910, but quarterly parades continued to be without pay, ${ }^{137}$ and after May $31^{\text {st }}$ control passed from Colonial into Union hands.

New manuals for the infantry and combined training were issued in 1907. Officers had to buy the combined training manual (15s.2d), and one may suppose the infantry one as well. The British Army's Officer's Field Note Book was also for sale at the Ordnance office,

\footnotetext{
${ }^{128}$ CGR 1908, p. 1, and 1909, p. 1.

${ }^{129}$ NGG 3594 (Feb. 12, 1907), p. 144: M.O. 48/07; 3598 (Mar. 12, 1907), p. 236: M.O. 75/07; 3644 ((Nov. 26, 1907), p. 1370: M.O. 260/07.

${ }^{130}$ CGR 1908, p. 1.

${ }^{131}$ CR 1907, p. 1.

132 Ibid., p. 4.

133 SYB 1908, p. 65, and 1909, p. 69.

${ }^{134}$ CR 1907., p. 1. NGG 3595 (Feb. 19, 1907), p. 178: M.O. 53/07.

${ }^{135}$ CGR 1908, p. 1. NGG 3664 (Mar. 24, 1907), p. 235: M.O. 54/08.

${ }^{136}$ CGR 1909, p. 1. NGG 2772 (Aug. 17, 1909), p. 731: M.O. 126/09.

${ }^{137}$ NGG 3813 (Feb. 10, 1901), p. 309: M.O. 16/10.
} 
but the number was limited. ${ }^{138}$

McKenzie was as keen as Leader had been about inspiring a martial spirit. In his report for 1907 he stated that two-thirds of men twenty-five and under were shirking their duty to the State by avoiding service in the Militia. ${ }^{139}$ When the peacetime strength fell below 2500 in 1908, he blamed it on a lack of interest and a decline in the volunteering spirit, and on reduced inducements and employers' opposition to joining the units. He urged compulsory military training on an equal basis, citing the Australian example. This way there would be no discrimination based on employment; employers would accept it when they could not deny it. Of course, for McKenzie this basic training should take place in the Active Militia, and afterwards the great majority would pass into the Reserves. ${ }^{140}$

The Militia Act had provided for a Permanent Militia corps, but one had never been established. In August of 1907 it seemed as if the government would introduce a bill for one, but then it declined to do so, ostensibly waiting to see if other colonies would undertake a joint effort. However, it did not let go of the matter. ${ }^{141}$ The Natal Police Reserve Force was practically such a force, and in 1907 the government sought to transfer command of it to the Militia. McKenzie professed not to desire this, and said that the initiative was entirely the government's. ${ }^{142}$ In his reminiscences, the Chief Commissioner of Police, W.J. Clarke, tells otherwise. ${ }^{143}$ "It is no secret that there is a great deal of jealousy between the Militia and the Police”, the Minister of Justice, T.F. Carter, told the Legislative Assembly when, in late September, he moved the passage of a bill to allow the transfer of command of the Reserve Force to the Commandant when it was in the field. ${ }^{144}$ Both sides had their partisans, and there was a sharp debate. The Police Reserve Force was already in Zululand, and more trouble was looming, so the measure appeared to be a practical one for operational unity of command. ${ }^{145}$ In December 1907 martial law was proclaimed and Active and Reserve Militia

\footnotetext{
${ }^{138}$ Ibid. 3624 (July 30, 1907), p. 831: M.O. 186/07); 3635 (Oct. 1, 1907), p. 1150: M.O. 227/07; 3649 (Dec. 10 , 1907), p. 1421: M.O. 268/07.

${ }^{139}$ CR 1907, p. 3.

140 Ibid., pp. 2-3. CGR 1908, pp. 1 and 5; and 1909, p. 1.

141 Debates, XLIII, 534, 652, 657, 660. The Commandant's annual report for 1907 was presented to the Legislative Assembly only in July, delayed by a question of its confidentiality, and members were obliged to read it and give their approval before it could be published. (Ibid XLII, 171-172.)

${ }^{142}$ CGR 1908, p. 5.

143 W.J. Clarke, My Career in South Africa, II, 21-22, 27. A copy of these reminiscences is in the Pietermaritzburg Archives Repository, but there are others elsewhere.

${ }^{144}$ Debates, XLIII, 650.

145 Ibid., 641-663. See Act No. 22 of 1907, in Colony of Natal, Acts of Parliament of the Colony of Natal
} 
forces, under McKenzie, invaded Zululand to ensure the arrest of Dinuzulu. There was no fighting and the crisis soon ended. ${ }^{146}$ A year after its passage, the Act consolidating command was narrowly repealed. ${ }^{147}$

The government was intent on clipping the wings of the Police in favour of the Militia, and did so. The strength of the Police was cut by 126 men which, in effect, eliminated the Reserve Force; ${ }^{148}$ and a Militia force, the Southern District Scouts, was formed to watch the border which had attracted much attention from the Police. ${ }^{149}$ This was no substitute for a permanent Militia force, but it was a regional one for the former Police Reserve. McKenzie was appointed Commandant General, Natal Colonial Forces, with effect from November 17, 1908. ${ }^{150}$

McKenzie had modest success with the Departmental corps. In 1907 the government authorized increases in the strength of the Medical, Service, and Telegraph corps. ${ }^{151}$ In the same year government postal and telegraph employees were only allowed to join the Telegraph Corps, and qualified men in the Field Artillery were allowed to transfer to it. ${ }^{152}$ At the end of the year a Remount Corps was established, and early in the next amalgamated with the Veterinary Corps. ${ }^{153}$ In 1908 an Intelligence corps was established, and the Colony was covered by a network of voluntary 'assistants' or officers. ${ }^{154}$ Transport was centralized under a Transport officer at headquarters, and requisitioning officers were appointed in December 1907, which facilitated McKenzie’s Zululand expedition. ${ }^{155}$ However, a Transport corps was formed only in early 1910, and, at the same time, an Engineers corps was also formed. ${ }^{156}$ For the three preceding years a Searchlight Detachment, which was intended to be part of it,

\footnotetext{
passed in the Second Session of the Fifth Colonial Parliament 1907 (Pietermaritzburg, Davis, 1907), p. 43.

${ }^{146}$ McKenzie's report of the expedition is in CR 1907, pp. 5-7. NGG 3646 (Dec. 2, 1907), p. 1379: GN 668 and 669/07; 3648 (Dec. 3, 1907), p. 1408: Proclamation 61/07; 3648A (Dec. 9, 1907), p. 1409A: Proc. 62/07; 3649 (Dec. 10, 1907), p. 1420: Notification by Commandant;

${ }^{147}$ Debates, XLV, 33-35, 150-153, 449-453. Cf Clarke, My Career in South Africa, II, 27-28.

148 Ibid., 27. Holt, Mounted Police, p. 219, says 226. Cf SYB 1908, p. 66 , and 1909, p. 70, which give 719 and 563 European mounted constables, respectively..

${ }^{149}$ NGG 3709 (Oct. 6, 1908), p. 388: M.O. 162 and 163/08.

${ }^{150}$ Ibid. 3721 (Nov. 24, 1908), p. 1174: M.O. 181/08. Hence CR becomes CGR in the notes.

${ }^{151}$ CR 1907, p. 1.

${ }^{152}$ NGG 3605 (Apr. 30, 1907), p. 375: M.O. 120/07.

${ }^{153}$ Ibid. 3661 (Mar. 3, 1908), p. 179: M. ). 33/08; 3662 (Mar. 10, 1908), p. 204: M.O. 44/08).

${ }^{154}$ CGR 1908, p. 6.

${ }^{155}$ CR 1907, p. 2. NGG 3649 (Dec. 10, 1907), p. 1422: M.O. 282 and 283/07.

${ }^{156}$ NGG 3813 (Feb. 15, 1910), p. 310: M.O. 29/10. See also CR 1907, p. 1, and CGR 1908, p. 4.
} 
functioned as a group of volunteers. ${ }^{157}$

A significant achievement was the centralization of procurement, care, storage and issue of arms and munitions, which Bru-de-Wold had urged earlier on. In 1907 the Militia Ordnance and Controllership of Arms were merged, but the Police held out another year. ${ }^{158}$ In 1908 the Militia’s firearms, ammunition and equipment were stored in designated government buildings in Pietermaritzburg and Durban under the control of a Chief Ordnance Officer. ${ }^{159}$ The next step was to overhaul the stocks in local depots throughout the Colony. Firearms were sent into the central store and repaired and serviced and a large quantity of obsolete firearms was destroyed. The intention was to send the serviced weapons back to local depots. These were usually country gaols under the magistrates' control, and the magistrates objected. The return was stopped, but then people in the country districts objected on grounds of security. ${ }^{160}$ Apparently the problem was still unresolved at the time of Union.

There were complaints from units that they were being issued second-hand equipment from Ordnance, but the Commandant insisted that it was perfectly serviceable and should be used up before new items were issued. ${ }^{161}$ For reasons of economy, corps officers were ordered to have their units collect empty cartridge cases and take care not to damage ammunition boxes so that they could be returned to stores ${ }^{162}$ for re-use - or perhaps not. In April 1910 the Ordnance department put to tender the purchase of cases of brass scrap, cartridge cases, ammunition and other boxes at the magazines at Pietermaritzburg and Durban. ${ }^{163}$ Men who damaged their equipment were to pay double for it. ${ }^{164}$ Only in 1909 were items issued from Ordnance stores given an official government mark, ${ }^{165}$ and in 1910 were detailed Ordnance Regulations and Equipment Tables published. ${ }^{166}$

\footnotetext{
${ }^{157}$ CGR 1909, p. 4.

${ }^{158}$ CR 1907, p. 3. CGR 1908, p. 4.

${ }^{159}$ CGR 1908, p. 4.

${ }^{160}$ Ibid. 1909, pp. 3, 5.

${ }^{161}$ NGG 3668 (Apr. 21, 1908), p. 310: M.O. 77/08.

162 Ibid. 3610 (June, 1907), p. 481: M.O. 152/07; 3629 (July 27, 1907), p. 988: M.O. 200/07; 3735 (Feb. 9 , 1909), p. 129: M.O. 24/09; 3772 (Aug. 17, 1909), p. 731: M. O. 129/09.

163 Ibid. 3822 (Apr. 12, 1910), p. 449: Tender, Apr. 6, 1910.

${ }^{164}$ Ibid. 2270 (Apr. 21, 1909), p. 800: M.O. 141/09.

165 Ibid. 3750 (May 4, 1909), p. 378: GN 221/09. Cf CGR 1908, p. 4, which suggests earlier.

${ }^{166}$ Very detailed. See NGG 3804 (Jan. 13, 1910), pp. 99-125: GN 27/10.
} 
In May 1910 the government generously fixed the peacetime establishment of the Active Militia at 4,680 - 4,341 in the field corps and 339 in the Departmental corps, exclusive of the Permanent Staff. This remarkable increase (84\% on strength at the end of 1909) was probably a wishful projection on the budget of the new Union. ${ }^{167}$

The Reserves as the mainstay of the Militia

The danger of a Boer insurrection and invasion receded. The Zulu Rebellion had been suppressed, but it left an imprint of danger in the settler mind. Against Native unrest and violence, the settlers found an ideal home guard in the Militia Reserve. Of course, it had to be properly organized and supported and, also, it had to be inexpensive.

"The Government has decided that the Reserve organization is the best suited for the defence of the Colony”, McKenzie stated in the Commandant General's annual report for 1908. ${ }^{168}$ His oft-expressed concern for the Active Militia and comparative reticence regarding the Militia Reserves in reports seem to cloak a personal disappointment. Henceforth, the Militia Reserves would be the mainstay of Natal's defence force. At the end of 1909 the Reserves numbered 17,770: 5,938 men in the First class; 8,086 in the Second; and 3,749 in Third. ${ }^{169}$

The new emphasis on the Reserves appears to be the result of a combination of political and economic pressures. The record of the Reserves called out during the Rebellion had been a mixed one, and in the midst of the crisis the government honoured its earlier undertaking to the Governor to introduce their training in peacetime. In July of 1907, Thomas Watt, the member for Newcastle and a former of Minister of Defence who had resisted the amendments to the Militia Act, moved in the Legislative Assembly that the government not exercise the power to call them out for training. The government made it clear that this was not its policy, and he withdrew the motion. ${ }^{170}$ A month later, T.P. O’Meara, member for Pietermaritzburg, moved the repeal of the Militia Act and a return to

\footnotetext{
${ }^{167}$ Ibid. 3837 (May 30, 1910), p. 629: M.O. 72/10. See the number for 1909 in SYB 1909, p. 74.

${ }^{168}$ CGR 1908, p. 3.

${ }^{169}$ Ibid.

${ }^{170}$ Debates, XLII, 255.
} 
the old Volunteer Act. The motion was defeated in a three-to-one vote. ${ }^{171}$

This happened when the Colony was between Governors in the winter of 1907, and the Administrator W. H. Beaumont remarked, in connection with the revised defence scheme, that the mobilization of the Reserves was still a matter of uncertainty; however, McKenzie disagreed. ${ }^{172}$ In fact, the Rebellion had demonstrated that the Colony could not do without the Reserves in a full blown crisis, and there could be no going back. If anything, they were more needed than ever. The Imperial garrison was too small to be effective in operations, and there was no guarantee neighbouring colonies would be so generous in despatching volunteers to help again. They were also cheaper. Government expenditure on Militia Reserves amounted to just $£ 1,232$ in $1907-1908$ and $£ 1,616$ in 1908-1909. ${ }^{173}$

At the time of the Zululand expedition in December 1907, units were called out in fourteen districts. The Commandant was pleased with the response, but again observed that they were handicapped by lack of training. Of course, they could not be trained in the same way as the Active Militia, and therefore would never attain parity with those corps, but they received at least some training on a regular basis. ${ }^{174}$ Some units seemed to fare better than others, notably the Pietermaritzburg City Reserves, which employed a sergeant of the Natal Carbineers as their sergeant major and instructor. ${ }^{175}$ The units in Greytown and the Umvoti and Krantzkop divisions were consolidated in a single district organization, as were those in the Lion's River and Impendhle divisions. ${ }^{176}$ Even the Natal Government Railways had a unit. $^{177}$

There was much chopping and changing of leaders, and Militia orders for the period are replete with appointments and resignations. In Pietermaritzburg and Weenen, leaders were appointed practically en bloc. ${ }^{178}$ In Durban, they resigned in like manner just before the

\footnotetext{
${ }^{171}$ See ibid., 586-611.

${ }^{172}$ GH 511, p. 140: Formation of a Local Defence Scheme for Natal (undated memorandum)

173 SYB 1908, p. 65, and 1909, p. 69. No Militia Order regarding uniform has been found, but there is a quite singular one (6/07 in NGG 3589, Jan. 8, 1907, p. 33) giving colours (dark blue with white stripes) to the Underberg Militia Reserves. See n. 184.

${ }^{174}$ CR 1907, p. 2.

175 Ibid. CGR 1908, p. 3. NGG 3612 (June 11, 1907), p. 532: M.O. 164/07.

${ }^{176}$ NGG 3642 (Nov. 12, 1907), p. 1330: M.O. 253/07.

${ }^{177}$ Ibid. 3780 (Oct. 12, 1909), p. 876: M.O. 148/ and 149/09.

178 See ibid. 3664 (Mar. 24, 1908), p. 235: M.O. 50/08; 3665 (Mar. 31, 1908), p. 249: M.O. 58/08; 3733 (Jan. 26, 1909), p. 75: M.O. 19/09; 3735 (Feb. 9, 1909), p. 129: M.O. 29/09.
} 
December 1907 crisis, ${ }^{179}$ suggesting that they had no intention of making themselves available for duty in Zululand. Leaders continued to be elected by the men and then appointed by the government, but there was a growing feeling that elections should be dispensed with, and McKenzie made recommendations accordingly. ${ }^{180}$ An increasing number of leaders also took the same examinations as Active Militia officers seeking promotion, and wished to be commissioned. An unsuccessful bill in the Legislative Assembly in September 1909 tried to provide for it. ${ }^{181}$ At this stage the government was willing to leave such matters for the Union to deal with. ${ }^{182}$

The transformation of the Militia was reflected in a transformation of Rifle Associations. Most of the Active Militia corps had their Rifle Clubs, ${ }^{183}$ and the Militia Reserve units followed their example. Reserves rifle teams appeared at the 1908 Bisley for the first time. ${ }^{184}$ McKenzie hoped that the clubs would "prove a better means of organising the Reserves", ${ }^{185}$ and their rules would "provide for giving each man plenty of practice in shooting”. ${ }^{186}$ Indeed, members were obliged to attend at least one parade of six hours or three of two and fire a prescribed course with a minimum score in order to qualify as efficient. $^{187}$ The Rules were gazetted at the end of $1908,{ }^{188}$ and twenty-four clubs were formed in $1909 .{ }^{189}$

Since all able-bodied men were enrolled in the Reserves and the Reserves could, and now officially should, have their Rifle Clubs, the Rifle Associations were superfluous as defence organizations. According to the Rifle Club Rules, a man could not belong to a Rifle Club and a Rifle Association. In 1907 there were 129 Rifle Associations with 5,567 efficients, not counting Natal Police and Militia. The government reduced its grants to them in 1907 when it was found that that two thirds of their members had lost or could not account

\footnotetext{
${ }^{179}$ Ibid. 3649 (Dec. 10, 1907), p. 1422: M.O. 280/07.

${ }^{180}$ CGR 1909, p. 3.

${ }^{181}$ Debates, XLVIII, 404, 479-481. Whatever their scores on paper, Reserve leaders did not have the training and practical experience of officers in the Active Militia.

182 Ibid., 480. CGR 1909, p. 3.

${ }^{183}$ CR 1907, p. 4.

${ }^{184}$ CGR 1908, pp. 2-3.

185 Ibid. 1909, p. 3

${ }^{186}$ Ibid. 1908, p. 3.

${ }^{187}$ NGG 3726 (Dec. 22, 1908), p. 1243: GN 723/08. If they wished, clubs could adopt uniforms (p. 1245).

${ }^{188}$ Ibid. pp. 1243-1246. CGR 1908, p. 4.

${ }^{189}$ CGR 1909, p. 3.
} 
for their ammunition. ${ }^{190}$ In 1909 there were 110 with only 3,962 efficients. ${ }^{191}$ The government gave notice that from January 1, 1910 it would no longer provide free ammunition or money grants to Rifle Associations, nor would it sell rifles and ammunition to them at cost. ${ }^{192}$ Existing associations were encouraged to convert to Rifle Clubs, ${ }^{193}$ which, in essence, meant becoming an adjunct of the Militia Reserves. Most of them did so, but naturally there was some dissatisfaction. ${ }^{194}$ There were exceptions. The Natal Rifle Association enjoyed the prestige of managing the Annual Prize Meeting, the so-called Natal Bisley, but even it had to change its constitution. ${ }^{195}$ It remained based at Pietermaritzburg, and it is not surprising that four of the seven Rifle Clubs first gazetted were formed in the City and its immediate vicinity. ${ }^{196}$

Then there were the new Miniature Rifle Clubs which appeared in 1908. The rifles and ammunition were light and inexpensive and suitable for the short ranges at drill halls and schools. McKenzie thought they would be good not only for School Cadets but for young men too busy with sport on Saturday afternoon who would do some shooting in the evening. ${ }^{197}$ (Perhaps he was thinking of attracting recent school leavers in the towns, for Senior Cadets had dwindled in number due to disciplinary problems.) ${ }^{198}$ In 1909 Miniature ranges were erected in Pietermaritzburg and Durban, and improved at twenty-two schools throughout the Colony. ${ }^{199}$

Like Bru-de-wold, McKenzie championed women’s use of firearms. "I am strongly of the opinion that every woman in the Colony should learn to use a rifle", he reported in 1909. ${ }^{200}$ If a district went into laager, they would add to the firepower of the defence. Women could join an existing Rifle Club - the Rules were amended in March $1909^{201}$ - or

\footnotetext{
${ }^{190}$ CR 1907, p. 3.

${ }^{191}$ SYB 1909, p. 69.

192 CGR 1909, p. 3. NGG 3814 (Feb. 26, 1910), p. 330: M.O. 33/10.

${ }^{193}$ NGG 3729 (Jan. 5, 1909), p. 8: M.O. 4/09.

${ }^{194}$ CGR 1909, p. 3.

195 NGG 3728 (Dec. 29, 1908, pp. 1265-1266: Notice.

${ }^{196}$ Ibid. 3743 (Mar. 23, 1909), p. 256: M.O. 55/09. There evidently was tension between Pietermaritzburg and Durban members, who wanted to alternate meetings between centres. See Debates, XLIX, 242-246.

${ }^{197}$ CGR 1908, pp. 3-4.

198 Ibid., pp. 2-3; 1909, p. 4. There were 453 Senior Cadets enrolled at the end of 1906, 241 at the end of 1908, and 89 in 1909. The Commandant considered disbandment, but left the matter for Union authorities to deal with.

${ }^{199}$ Ibid., 1909, p. 4.

${ }^{200}$ Ibid. 1908, p. 4.

${ }^{201}$ NGG 3744 (Mar. 30, 1909), p. 268: GN 155/09.
} 
form one of their own. McKenzie reported that Miniature rifles were suitable for girls over fourteen. Ranges were to be built at girls' schools where possible, and the government would provide for instruction. ${ }^{202}$ According to the Commandant, the first course in shooting, held at the Drill Hall in the City, "met with the greatest success". ${ }^{203}$

The Imperial factor again

Imperial intervention in Natal's defensive arrangements continued after the Rebellion, but events in Europe were turning the attention of the British government, the Army Council and the reorganized General Staff more and more towards the impending conflict there. Inevitably, if not immediately, the attention of colonial politicians and officers was drawn thither as well. The diplomatic revolution in Europe was practically completed when Britain reached an understanding with Russia in 1907. At the Colonial Conference in 1907 it was apparent that Britain was preoccupied with the possibility of a major war in Europe and interested chiefly in finding out what help it could expect from the Empire. ${ }^{204}$ In October 1908, on the initiative of the Imperial authorities, a Defence Conference was held in Durban. The commandants of the South African colonies attended. "The general idea [...] was to assimilate as far as possible the organization and training of the South African Colonial Forces”, reported McKenzie, "and as far as possible this is being done”. ${ }^{205}$ In early 1909, at the height of the Dreadnought crisis, the Imperial authorities held a special naval and military conference, ${ }^{206}$ whose proceedings were confidential and secret. Colonel E.M. Greene, of the Natal Carbineers and a member of the legislative assembly, attended on behalf of Natal, but he would only tell members of the Legislative Assembly that Natal had not agreed to do anything which it was not doing already. ${ }^{207}$

In early 1907 the Prime Minister, Frederick Moor, called at the War Office while on a visit to London, and asked about an exchange of Imperial and Colonial officers and admission of the latter to the Staff College at Camberley. He also asked for information about the General Staff, which had been established in September 1906. The Director of

\footnotetext{
${ }^{202}$ CGR 1908, p. 4.

${ }^{203}$ Ibid. 1909, p. 4.

${ }^{204}$ Hyam, Britain's Imperial Century, p. 167. Bond, Victorian Army and the Staff College, p. 237.

${ }^{205}$ CGR 1908, pp. 5-6.

${ }^{206}$ Carrington, British Overseas, p. 858.

${ }^{207}$ Debates XLVIII, 241-245.
} 
Staff Duties, Major-General Hutchinson, consequently sent him copies of the Special Order for the Organization of the General Staff (and Viscount Haldane's expository memorandum), Staff College Regulations, and Revised Regulations under which Colonial officers might obtain commissions in the British Army. These papers the Prime Minister forwarded to the Commandant. ${ }^{208}$ Evidently they had some impact.

The Militia Staff seems not to have been much affected, at least in form. District Commandants had been dispensed with, but a Commandant of Reserves was appointed, and officers were appointed in the new Departmental corps. There certainly was an effort to improve regimental officers’ qualifications. In January 1907 Militia Orders offered Imperial military publications at reduced rates. ${ }^{209}$ From February 1906 until July 1908 Militia Orders listed new accessions to the library, ${ }^{210}$ although early in March 1907 "the Commandant observe[d] with regret that officers had not availed themselves [of the Militia Library] to the extent which he could have desired", and he reminded them that catalogues could be obtained at Militia Headquarters. ${ }^{211}$

The regulations for obtaining commissions in the British Army, with detailed appendices, were gazetted in July 1907, January 1908, and February $1909 .^{212}$ The qualifications were strict. Annually, there were fifteen commissions available to colonials, three of which were reserved for South Africa. ${ }^{213}$ Admission to the Royal Staff College was also restricted. $^{214}$ The first Natal officer to enter was Captain W.E. Tanner, of the Militia Staff, in 1909. ${ }^{215}$

Colonial officers and detachments were invited to take part in the Imperial forces'

\footnotetext{
${ }^{208}$ Natal Defence Records 5/2: V3228/07, Maj.-Gen. to PM, May 29, 1907, and reply, June 26, 1907. The commission regulations were forwarded separately by the Agent-General in London (V4097/07).

${ }^{209}$ NGG 3589 (Jan. 8, 1907), p. 33: M.O. 5/07; also 3635 (Oct. 1, 1907), p. 1150: M.O. 229/07.

${ }^{210}$ See NGGs between those dates for the lists. Military intellectuals may have found some satisfaction later in the founding of a Military Society in June 1909. (Ibid. 3913 (June 22, 1909), p. 592.)

${ }^{211}$ Ibid. 3597 (Mar. 5, 1907, p. 231: M.O. 67/07.

${ }^{212}$ NGG 3630 (Sept. 3, 1907), p. 101: M.O. 209/07; and 3734 (Feb. 2, 1909), pp. 96-103: M.O. 21/09. See also Regulations in NDR 5/2: V4097/07 (see n. 81).

213 Ibid. 3734, p. 96.

${ }^{214}$ Ibid. 3656 (Jan. 28, 1908), p. 88: M.O. 12/08. See also Regulations in NDR 5/2: V3228/07 (see n. 84).

${ }^{215}$ CGR 1909, p. 2, which also mentions that Lieut.-Col J. Hyslop, Principal Medical Officer, was granted extra leave while in England to study military medical administration. Bond, The Victorian Army and the Staff College, p. 238, states that two Natal officers passed through the Staff College between 1903 and 1911, and mentions no other South Africans.
} 
annual camps in the Transvaal in September 1907,, ${ }^{216}$ and the Commandant, Chief Staff Officer and Natal Field Artillery commander did so in August $1908 .^{217}$ In July 1909 a Natal Colonial Forces Military Tournament was held in Durban for the purpose of encouraging and developing "skill at arms" among all ranks. ${ }^{218}$ The tournament was opened by the General Officer Commanding and Acting Governor of the Transvaal, Lord Methuen. Imperial and naval units were also invited, and all participated "in friendly rivalry", according to McKenzie, who hoped that the event would become an institution. ${ }^{219}$

Shooting was all-important to defence, and every endeavour was made to promote and perfect it. New ranges were laid out in Pietermaritzburg and Durban in 1907, and whatever else he had to say about the Active Militia, McKenzie reported that its standard of shooting was very high. ${ }^{220}$ Militia units, Cadet Corps, Rifle Associations and Rifle Clubs all had their regular shoots, with appropriate prizes for individuals and for teams. Empire-wide competitions were introduced on Empire Day. ${ }^{221}$ Sir Henry McCallum and his successor Sir Matthew Nathan (1907-1909) offered special prizes. Sir Matthew (also a Royal Engineer) laid down that his prize should be awarded for shooting in approximate field conditions. ${ }^{222}$ Lord Methuen, the last governor (1910), had introduced a South African cup in early 1909, when he was in command of the forces. ${ }^{223}$ In 1907 the Militia and the Natal Rifle Association combined their annual shootings in one annual Natal Bisley. ${ }^{224}$ School Cadets were allowed to participate in it in 1909, after the shooting age for Cadets was raised from thirteen to fourteen.

The Militia was introduced to a new course of musketry, based on the standards of the Imperial service, in $1907,{ }^{225}$ but the regulations were amended at the beginning of $1908 .{ }^{226}$ In mid-1909, a new course for South African Local Forces, incorporating the recent

\footnotetext{
${ }^{216}$ NGG 3620 (July 9, 1907), p. 690: M.O. 177/07.

${ }^{217}$ Ibid. 3698 (Aug. 25, 1908), p. 799: M.O. 140/08.

${ }^{218}$ Ibid. 3766 (July 13, 1901, p. 649: M.O. 116/09; and 3767 (July 20, 1909), p. 674: M.O. 120/09.

${ }^{219}$ CGR 1909, p. 2. Apparently it was not such a financial success, for the government had to pay $£ 400$ in costs when Durban could not. See Debates XLIX, 244.

${ }^{220}$ CR 1907, p. 2 and 4.

${ }^{221}$ See NGG 3669 (Apr. 28, 1908), pp. 322-323: M.O. 85/08. 3743 (Mar. 23, 1909), pp. 256-257: M.O. 57/09;

3750 (May 4, 1909), pp. 384-385: M.O. 83/09.

${ }^{222}$ CR 1907, p. 2, and CRG 1908, p. 2.

${ }^{223}$ NGG 3730 Jan. 12, 1909, p. 212: M.O. 9/09.

${ }^{224}$ CGR 1908, p. 2, and 1909, p. 5

${ }^{225}$ CR 1907, p. 4.

${ }^{226}$ NGG 3654 (Jan. 14, 1908), pp. 34-36: M.O. 10/08.
} 
experience of Imperial and European armies, was introduced. ${ }^{227}$ It was too complicated for Militia in the country districts, ${ }^{228}$ and the regulations were amended early in $1910 .{ }^{229}$ In October 1909 a Combined Senior Officers and Refresher Musketry Course, for Imperial and Colonial officers, was held at Bloemfontein. ${ }^{230}$ Officers in the Field Artillery and Departmental corps were armed with pistols, and from 1907 were required to take a revolver course. ${ }^{231}$ That year mounted revolver shooting was introduced at the annual Bisley. ${ }^{232}$

The contentious post-war issues of defence between the Colony and the Imperial authorities faded after the Rebellion. For one thing, the Rebellion pointed to the wisdom of maintaining an Imperial garrison in the Colony, as much to show moral and political support as military strength. No longer was Fort Napier manned by the expedient Royal Garrison Regiment, but by a succession of battalions of regular regiments. ${ }^{233}$ Ironically, their presence was rendered less urgent by the completion of the Natal Defence Scheme which General Hildyard and Sir Henry McCallum had sought in 1905.

The duality of policy, which had characterized the Defence Committee before Leader's departure and the reduction of Imperial strength in 1905, was gone. The Imperial viewpoint was represented by the Chief Staff Officer, South Africa, but he was stationed in Pretoria, and the rest of the members of the committee were Colonial officers and politicians. ${ }^{234}$ In the absence of surviving records of the committee one is left to guess at the opinions and actions of its members, but Sir Henry’s fear that a Colonial Commandant would not be able to resist the politicians seems to have been borne out by McKenzie's frustration seeking to augment the Active Militia and mould the Militia Reserves as he wished.

The Natal Defence Scheme was updated to meet changed circumstances. In July 1907 Administrator W.H. Beaumont read the draft of Bru-de-Wold's revised scheme, which provided for the fielding of 4,356 men of all ranks and the manning of fifty-six blockhouses. He remarked that a Boer rising now seemed very unlikely, and asked after a new scheme to

\footnotetext{
${ }^{227}$ Ibid. 3737 (Feb. 16, 1909), p. 171: M.O. 33/09.

${ }^{228}$ CGR 1909, p. 2.

${ }^{229}$ NGG 3805 (Jan. 18, 1910), p. 161: M.O. 9/10.

${ }^{230}$ Ibid. 3732 (Aug. 17, 1909), p. 730: M.O. 124/09.

${ }^{231}$ Ibid. 3591 (Jan. 22, 1907), pp. 89-90: M.O. 24/07. CR 1907, p. 4.

${ }^{232}$ CR 1907, p. 2.

233 See GH 520, p. 17:G24/07, Maj.-Gen. i/c Admin. to Gov., Mar. 26, 1907; and for succeeding regiments, Natal Directory 1908 and 1909, pp. 38 and 38, respectively, and Brookes and Webb, History of Natal, p. 207.

${ }^{234}$ See Natal Civil List 1906, p. 182; 1907, p. 169; 1908, p. 174; and 1909, p. 181.
} 
meet a Native one. McKenzie replied that the Boer one he had to hand was what the Army Council wanted. There was in fact another scheme for a Native rising, and several others were under consideration. ${ }^{235}$ Even so, the Zululand expedition in December reflected elements of the 1904 mobilization scheme.

In 1908 the Imperial authorities desired the colonies to prepare new schemes to deal with a general Native uprising in South Africa. Militia devised one, which assumed that Imperial forces and loyal Native levies would not be available to assist in Natal. The Colony was divided into nine districts under commandants, with seventy-six laagers and rallying points under laager commandants and leaders, respectively. These places were to be surrounded by barbed wire entanglements and supplied with ammunition and provisions. Settlers' families would resort to these defences, which would be manned by the Third Reserves and some of the First and Second. Railways staff and employees would form laagers and erect blockhouses along the rail lines. The Active Militia and the bulk of the First and Second Reserves would mobilize and form mobile columns at Durban, Pietermaritzburg, Greytown and Ladysmith. Each column would number 2,500 mounted and 1,000 unmounted men. The columns would seek out and destroy the enemy according to circumstances. The duties and purposes of the various units and the responsible officers were spelt out in detail. $^{236}$

Lord Methuen asked for the scheme in March 1909, and in July, Nathan forwarded the draft - although the Defence Committee had not approved it yet. The General wrote that the scheme was "very lucid and valuable", and made only a few minor suggestions for its improvement. ${ }^{237}$ He had also requested the other scheme which Militia was preparing, and it was sent to him in September. It was a plan for war with Germany. ${ }^{238}$

\footnotetext{
${ }^{235}$ GH 511, pp. 139-141: G116/07, Formation of a Local Defence Scheme for Natal (undated memorandum), and comments. McKenzie evidently was referring to Mobilization Schemes, which were components of the Defence Scheme.

${ }^{236}$ Ibid. 512, pp. 2-4: G826/09, Gov. to GOC, July 15, 1909.

${ }^{237}$ Ibid., pp. 5-6: GOC to Gov., Aug. 3, 1909.

${ }^{238}$ Ibid., pp. 2,4: Gov. to GOC, and p. 7: Admin. to GOC, Sept. 19, 1909. See also GH 1284, p. 22: Gov. to S/S, Mar. 26, 1910.
} 


\section{Conclusion}

In seventeen years of self-government the Colony of Natal had established a system of defence against indigenous enemies and foreign enemies. In comparing the states of defence in 1893 and 1910, one is struck by the remarkable difference. In 1893 there were no major enemies immediately threatening the British Empire or the Colonial regime, and the legislation organizing the Natal Police and Volunteer Force in 1894 and 1895 seemed quite adequate. The unexpected and sudden onset of war and then rebellion destroyed complacency, and tested the capacity and will of the settlers to fight foes without and then within.

From 1902 a major reassessment of defence took place. The Militia Act of 1903 provided for compulsory military training, but financial constraint inhibited the expansion of the Active Militia and popular suspicion delayed the formation of the Militia Reserves. Imperial authority had to be brought to bear on the Colony to complete the organization of the Militia. The process was marked by an unprecedented militarization of the settler population and sustained by an intensified patriotism (or nationalism) among them.

By the time of Union, the Colony was prepared to deal with an internal enemy, but it was not so well prepared to deal with an external one. The threat from outside the Colony had receded. Former Boer enemies were now compatriots, and potential German ones were far away. The efficient Militia organization remained in being under the Union, and provided a model for the Union Defence Force established in 1912. 